\title{
Unveiling the diversity of Phalangodus Gervais, 1842 (Opiliones: Cranaidae): descriptions of four new species from Colombia
}

\author{
Osvaldo VILLARREAL M. ${ }^{1, *} \&$ Andrés F. GARCÍA ${ }^{2}$ \\ 1,2 Departamento de Invertebrados, Museu Nacional/UFRJ; Quinta da Boa Vista, \\ São Cristóvão, 20.940-040, Rio de Janeiro, RJ, Brazil. \\ *Corresponding author: osvaldovillarreal@gmail.com \\ ${ }^{2}$ Email: agarciarinc@gmail.com \\ ${ }^{\text {urn:lsid:zoobank.org:author:BD0FCD76-887C-4789-977A-31372476E7F9 }}$ \\ ${ }^{2}$ urn:1sid:zoobank.org:author:CAFDA7B4-E6BC-489A-9608-DB8525E1EE38
}

\begin{abstract}
The Cranaidae genus Phalangodus Gervais, 1842 is revisited and its species are diagnosed. An identification key for the males of Phalangodus is provided. Four Colombian species are described as new: Phalangodus briareos sp. nov. from a cave in Zapatoca, Santander department, P. cottus sp. nov. from Villavicencio, Meta department, $P$. gyes sp. nov. from Ibagué, Tolima department and $P$. kuryi sp. nov. from Sierra Nevada de Santa Marta, Magdalena department. SEM images of the penis of Phalangodus, including the type species of the genus, P. anacosmetus Gervais, 1842, are provided for the first time. Sexual dimorphism and the morphology of stylar caps and ovipositor in Cranaidae are discussed. Additionally, we revised the geographical distribution of $P$. anacosmetus, including a map with the geographical records of the genus.
\end{abstract}

Key words. Cranainae, Gonyleptoidea, Laniatores, Neotropics, Ovipositors, Stylar caps.

Villarreal M.O. \& García A.F. 2016. Unveiling the diversity of Phalangodus Gervais, 1842 (Opiliones: Cranaidae): descriptions of four new species from Colombia. European Journal of Taxonomy 242: 1-41. http://dx.doi. org/10.5852/ejt.2016.242

\section{Introduction}

Cranaidae is the third most numerous family among Gonyleptoidea with 166 species (Kury 2013; Hara et al. 2014; Kury \& Villarreal 2015; Villarreal et al. 2015). The taxonomy and systematics of this group are complicated and the generic boundaries are poorly defined, as partially explained by Villarreal et al. (2015). The three main issues that lead to this situation are: 1) antique diagnoses of the genera that still follow the Roewerian system of classification, i.e., use of variable characters to establish artificial groups, as shown by several authors (e.g., Piza 1942; Kury 1990; Villarreal et al. 2015); 2) underestimation of the specific richness of many cranaid groups (the first author is working on an ongoing revision of the family) and 3) lack of revision, only a few genera have been revised according to modern standards (i.e., Pinto-da-Rocha \& Kury 2003; Pinto-da-Rocha \& Bonaldo 2011; Kury 2012a; Hara et al. 2014; Villarreal et al. 2015). 
The Andean genus Phalangodus Gervais, 1842 is among the few genera well studied taxonomically (Kury 1996; Hara et al. 2014). Despite being composed of large and common harvestmen (dorsal scutum length $=9-13 \mathrm{~mm}$ ), its specific richness is still underestimated. It was described as a monotypic genus (P. anacosmetus Gervais, 1842) in Gonyleptidae, without any subfamilial assignment and was posteriorly, included in Mitobatinae (Simon, 1879). Afther that, Roewer (1913) transferred the genus to Pachylinae Sørensen, 1884. More than 80 years later, Kury (1996) transferred Phalangodus to Cranaidae, redescribed the type species of the genus, proposed the Iquitosa Roewer, 1943 as a junior synonym of Phalangodus and synonymized Allocranaus giganteus Mello-Leitão, 1940 with P. anacosmetus. Finally, Hara et al. (2014) revalidated Iquitosa and synonymized Temucus Roewer, 1943 with Phalangodus.

In the present article, four new species from Colombia are described and diagnosed, based on material of Phalangodus studied from four arachnological collections. A key to identify males of the genus is provided. Sexual dimorphism and morphology of the stylar caps in Cranaidae is discussed.

\section{Material and methods}

The description standard and morphological terminology follow Villarreal et al. (2015) and integumentary ornamentation follows Da Silva \& Gnaspini (2009). Ovipositor terminology follows Townsend et al. (2015) with modifications here proposed. Outline shape of dorsal scutum follows Kury et al. (2007) extended in Kury \& Medrano (2016). Pedipalpal tibia and tarsus setation formula follows Mello-Leitão (1939), as explained and used in Pinto-da-Rocha (1997) and Villarreal-Manzanilla \& Pinto-da-Rocha (2006). Tarsal formula (numbers of tarsomeres from tarsus I-IV): counts are given from left to right side of each specimen; numbers in parentheses denote quantity of tarsomeres in distitarsus I-II.

The nomenclature of the macrosetae of penis ventral plate follows Kury \& Villarreal (2015) with the following modification: in Phalangodus there is an increase of the number of macrosetae that makes it difficult to distinguish between some MS groups (e.g., MS D from MS C or MS B from MS A). We are not able to identify homologies between these MS groups, but we can observe, at least, one proximal and one distal cluster. By using relative position and comparison with other related genera, these groups are here called MS A/B and MS C/D respectively, without ruling out the presence or absence of any groups, i.e., postulating either (1) presence of MS A and MS B proximally, or MS D and MS C distally or (2) presence of only one of the distal groups MS C or MS D or (3) presence of only one of the proximal groups MS A or MS B. A particular case occur in P. kuryi sp. nov. where all the MS are grouped, for the same reason named MS A/D.

Color descriptions use the standard names of the 267 Color Centroids of the NBS/IBCC Color System, using the Descriptive Color Names Dictionary (http://people.csail.mit.edu/jaffer/Color/Dictionaries\#nbs-

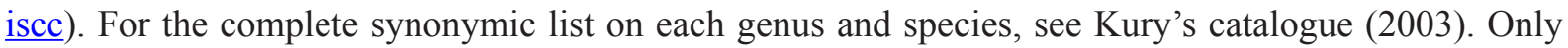
references from 2003 on are mentioned here.

Scanning Electron Microscopy of genitalia was carried out with a JEOL JSM-6390LV at the Center for Scanning Electron Microscopy at the Museu Nacional/UFRJ. The pictures of specimens were made using a digital camera Sony Cybershot DSC-v1 and assembled and edited the images of limited focal planes using Combine ZP Suite (by Alan Hadley) and Photoshop CC softwares. The drawings were made using a camera lucida attached to a stereomicroscope and processed with the software Inkscape v.0.91. Measurements were made using ImageJ v.1.50i Suite (by Wayne Rasband). The map with distribution of the species was made using Quantum Gis 2.2.0 software (QGIS Development Team 2014). Coloured areas mean WWF Terrestrial Eco-regions of the World (Olson et al. 2001, here abbreviated as WWF). 
The etymology for three of the species here described refers to Hecatonchires, three Greek mythological giant creatures (sons of Gaia and Uranus). The presence of numerous $\mathrm{A} / \mathrm{C}$ macrosetae in the penis of these species bears resemblance with the hundred hands typical of Hecatonchires.

\section{Morphometric abbreviations}

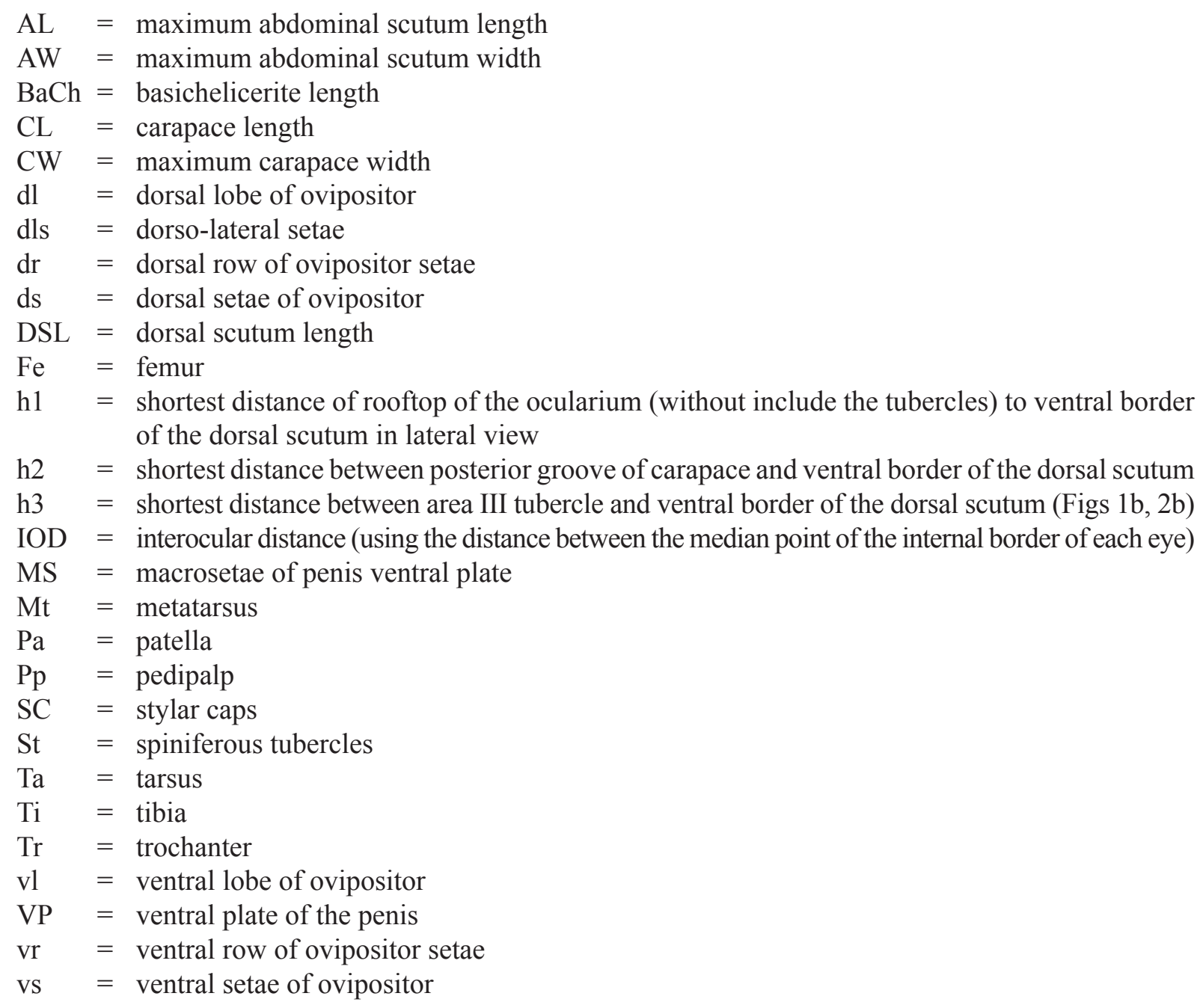

\section{Depositories}

The abbreviations follow Kury (2003):

CAS-AK $=$ California Academy of Sciences, Adriano Kury code (San Francisco, California, USA)

FMNH $=$ Field Museum of Natural History (Chicago, Illinois, USA)

ICN-AO = Instituto de Ciencias Naturales-Arachnida Opiliones (Bogotá, Cundinamarca, Colombia)

MNHN = Muséum national d'Histoire naturelle (Paris, France)

MNRJ = Museu Nacional /Universidade Federal do Rio de Janeiro (Rio de Janeiro, Brazil)

MZUSP = Museu de Zoologia da Universidade de São Paulo (São Paulo, Brazil)

UFMG = Universidade Federal de Minas Gerais (Belo Horizonte, Minas Gerais, Brazil) 


\title{
Results
}

\author{
Class Arachnida Cuvier, 1812 \\ Order Opiliones Sundevall, 1833 \\ Infraorder Grassatores Kury, 2002 \\ Superfamily Gonyleptoidea Sundevall, 1833 \\ Family Cranaidae Roewer, 1913
}

Genus Phalangodus Gervais, 1843

Phalangodus Gervais, 1842: 2 (see the complete citations in Kury 2003: 96).

Chauveaua Canals, 1939 [part] revalidated by Ringuelet 1957: 17.

Allocranaus Mello-Leitão, 1940: 307 [part].

Allocranaus - Kury 1996: 178. - Kury 2003: 96. — Hara et al. 2014: 568.

Phalangodes [misspelling] - Erichson 1845: 267. — Agassiz 1846: 10.

Phalangodus - Hara et al. 2014: 568.

\section{Type species}

Phalangodus anacosmetus Gervais, 1842, by monotypy.

\section{Diagnosis}

Large (DSL 9.0-13.4) cranaine. Outline of dorsal scutum type alpha, with lateral borders smooth or with few granules (densely granulate in $P$. palpiconus). Ocularium high (P. briareos sp. nov., P. cottus sp. nov., $P$. gyes sp. nov. and P. palpiconus) or low (P. anacosmetus and $P$. kuryi sp. nov.). Scutal area I divided into two halves; II invading scutal area I; III with a pair of enlarged tubercles or moderately high spines (absent in P. kuryi sp. nov.); IV entire (except in P. palpiconus) in left and right halves. Stigmatic area with a ventral pair of groups of granules (except in $P$. kuryi sp. nov.). Pedipalp: Femur convex dorsally, with a dorsal row of enlarged tubercles; ventrally with a few tubercles restricted to medial region, bearing an enlarged basal apophysis; claw of the males conspicuously thickened (P. anacosmetus, P. briareos sp. nov. and P. palpiconus). Metatarsus I of males not distally swollen. Femur IV of the males straight (P. briareos sp. nov., P. gyes sp. nov., P. palpiconus and $P$. kuryi sp. nov.) to slightly curved (P. anacosmetus and $P$. cottus sp. nov.), with a retrolateral distal/subdistal conical, enlarged tubercle (absent in $P$. gyes sp. nov. and $P$. kuryi sp. nov.). Penis: Ventral plate slightly longer than wide, with convex lateral borders, wide and shallow cleft on distal border. Setae on ventral plate organized in distal (9-12 pairs of MS C/D) and basal sets (4-5 pairs of MS A/B) or placed continuously (as a single set). Microsetae of the ventral plate present. Glans inflated medially. Stylus straight, surpassing distally the ventral plate (sligtlhy curved in $P$. kuryi sp. nov.), distal tip widened and rounded, with erythrocytric-like stylar caps stylar caps.

\section{Keys to males of Phalangodus}

1. Very low ocularium (Fig. 13b-c); femur IV of the males without any conspicuous spines (Fig. 14d); femora of the pedipalps in alpha males much more swollen than beta males (Fig. 14c, g); penis stylus curved (Fig. 15c, e) Phalangodus kuryi sp. nov.

- High ocularium, femur IV of the males sometimes with conspicuous spines (Figs 5c, 9f, h); femora of the pedipalps in males monomorphic (normally swollen) (Figs 9b, 11b); penis stylus straight (Figs 10e, 11a, d) 


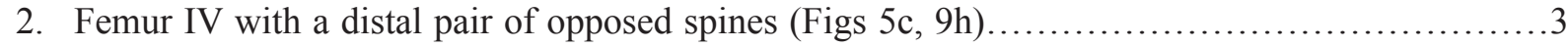

- Femur IV without distal spines (Fig. 11d), or with a retrolateral distal slightly curved spine (see,

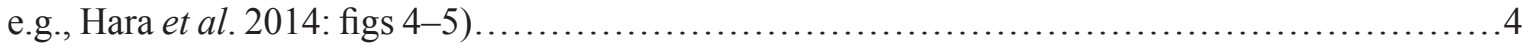

3. Proximal portion of femur II with large ventral tubercles arranged in two short rows (Fig. 9d, e); tibia IV with a retrolateral row of spines (Fig. 9g); two pairs of MS A-B (Fig. 10a, b); base of the pedipalpal claw not swollen Phalangodus cottus sp. nov.

- Proximal portion of femur II with a single median, curved tubercle (Fig. 5e, f); tibia IV without a retrolateral row of spines (Fig. 5d); 7 pairs of MS A/B (Fig 6b-c); base of the pedipalpal claw swollen and dark

Phalangodus briareos sp. nov.

4. Femur IV without distal spine (Fig. 11e); tibia with a proximal group of conical, irregularly sized tubercles in the prolateral side (Fig. 11d).

Phalangodus gyes sp. nov.

- Femur IV with a retrolateral distal curved spine (see Kury 1996: fig. 1); tibia with sparsely distributed tubercles of similar size on the prolateral side

5. Lateral border of DS and scutal area I smooth, ocularium low, ellipsoidal (Fig. 1a-d); femur IV sinuous (see Kury 1996: fig. 1); pedipalpal femur with a dorsal row of tubercles

Phalangodus anacosmetus Gervais, 1842

- Lateral border of DS and scutal area I densely granulate (see, e.g., Hara et al. 2014: figs 2-3); ocularium high, rounded, femur IV straight; pedipalpal femur with sparsely distributed tubercles

Phalangodus palpiconus (Roewer, 1943)

Phalangodus anacosmetus Gervais, 1842

Figs 1-3, 16a, 18-19

Phalangodus anacosmetus Gervais, 1842: 3, pl. 4 (see the complete citations in Kury 2003: 96)

Allocranaus giganteus Mello-Leitão, 1940: 307, fig. 8 (see the complete citations in Kury 2003: 96).

Phalangodus anacosmetus - Hara et al. 2014: 569.

Allocranaus giganteus - Hara et al. 2014: 569 (junior subjective synonym of Phalangodus anacosmetus Gervais, 1842 by Kury 1996).

\section{Diagnosis}

See Kury (1996) and Hara et al. (2014).

\section{Material examined}

\section{Data about type material}

Phalangodus anacosmetus: 1 ô, 1 क , syntypes (MNHN), Colombia, coll. Simon, N $\mathrm{N}^{\mathrm{o}}$ 1734, examined on photograph; 1 §, syntype (SMF RI 781), Colombia, coll. Simon, not examined.

Allocranaus giganteus: 1 , lectotype and 1 juvenile ${ }^{\lambda}$ paralectotype (MNRJ 00126), North of Santander, Cúcuta [original description cited as environs of Bogotá], Nicéforo Maria leg., examined.

\section{Addtional material examined}

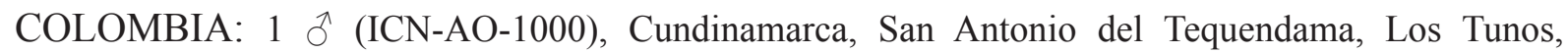

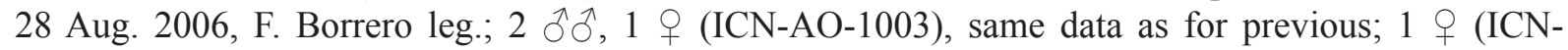
AO-1049) San Antonio del Tequendama, R.N. Los Tunos, 2300 m, 28 May 2012, D. Martínez leg.; 2 우, 2 juveniles (ICN-AO-521), San Antonio del Tequendama, Vereda Quintas Colombia, 1733 m, $4^{\circ} 35^{\prime} 48.72^{\prime \prime}$ N, 74¹9'40.19" W, 20 Aug. 2008, R. Botero, D. Luna and J.A. Ochoa leg.; 1 ๙ै (ICN- 
AO-525), La Mesa, Vereda Anatoly, road to El Espejo crag, 2100 m, 0441.593" N, 74²3.848" W, 21 Aug. 2008, J. Ochoa, D. Luna and E. Florez leg.; 1 § (ICN AO 1462), La Mesa, Puerto Lleras, vereda Hato Grande, 1300 m, 440'36.11" N, 74²5'17,07” W, 10 Apr. 2013, S. Galvis leg.; 1 P (CAS-AK 019), Cundinamarca, farm Bella Vista, near Sasaima, collected at night on low foliage, 13 May 1965, P.R. and D.L. Craig leg.

\section{Complementary description}

Coloration (in alcohol) (Figs 1-2). Carapace reticulated golden brown 75 over oak brown 55. Ocularium, mesotergal areas and central region of carapace oak brown 58. Posterior border of dorsal scutum, free tergites and coxae I-IV maroon 44. Dorsal surface of trochanters and posterior area of the carapace with
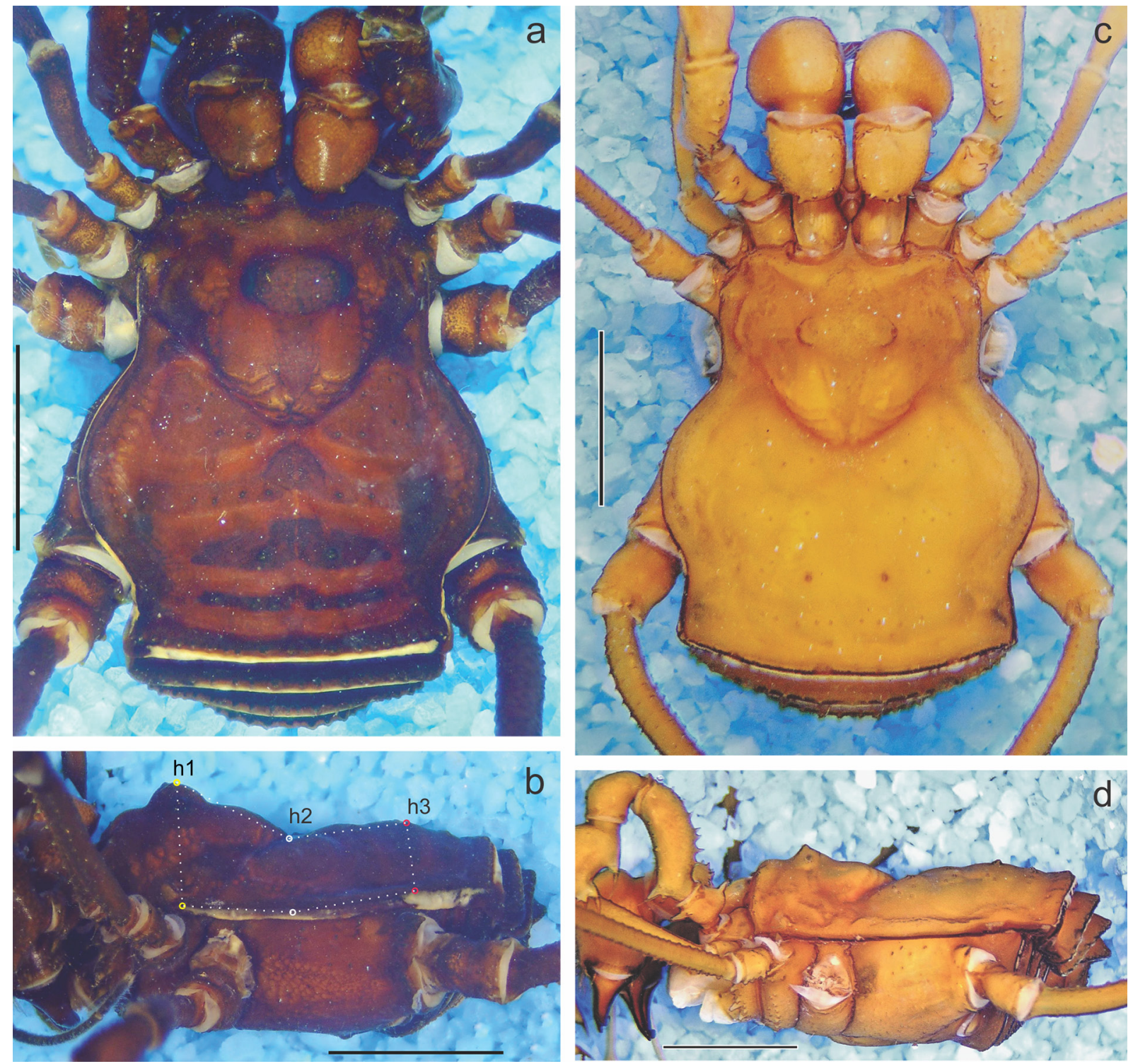

Fig. 1. Phalangodus anacosmetus Gervais, 1842, § (ICN-AO-1000). a. Habitus, dorsal view. b. Habitus, lateral view, + (CAS 0019). c. Habitus, dorsal view. d. Habitus, lateral view. Scale bars $=5 \mathrm{~mm}$. Abbreviations: see Material and methods. 
a reticulated pattern marigold 68. Legs (except coxae and trochanters) oak brown 58. Pedipalp coxae ventrally oak brown 55 with small areas russet orange 51; femur-tarsus red mahogany 41.

FEMALE (CAS-AK 019). Similar to male, differing by: ocularium narrower; coda wider; movable finger of chelicerae thinner; pedipalpal femur lower and thinner in lateral view, with ventroproximal tubercles smaller, claw not swollen; h1 thinner than in male (Fig. 1b, d); stigmatic area without the groups of granules anteriorly to stigmata; genital operculum wider than in male; femur IV without retrolateral distal spine; trochanters III-IV narrower.

\section{Remarks}

The material collected in Cúcuta (that corresponds to the syntypes of Allocranaus giganteus) presents the following differences compared with those from Cundinamarca: (1) ocularium not surpassing the scutal

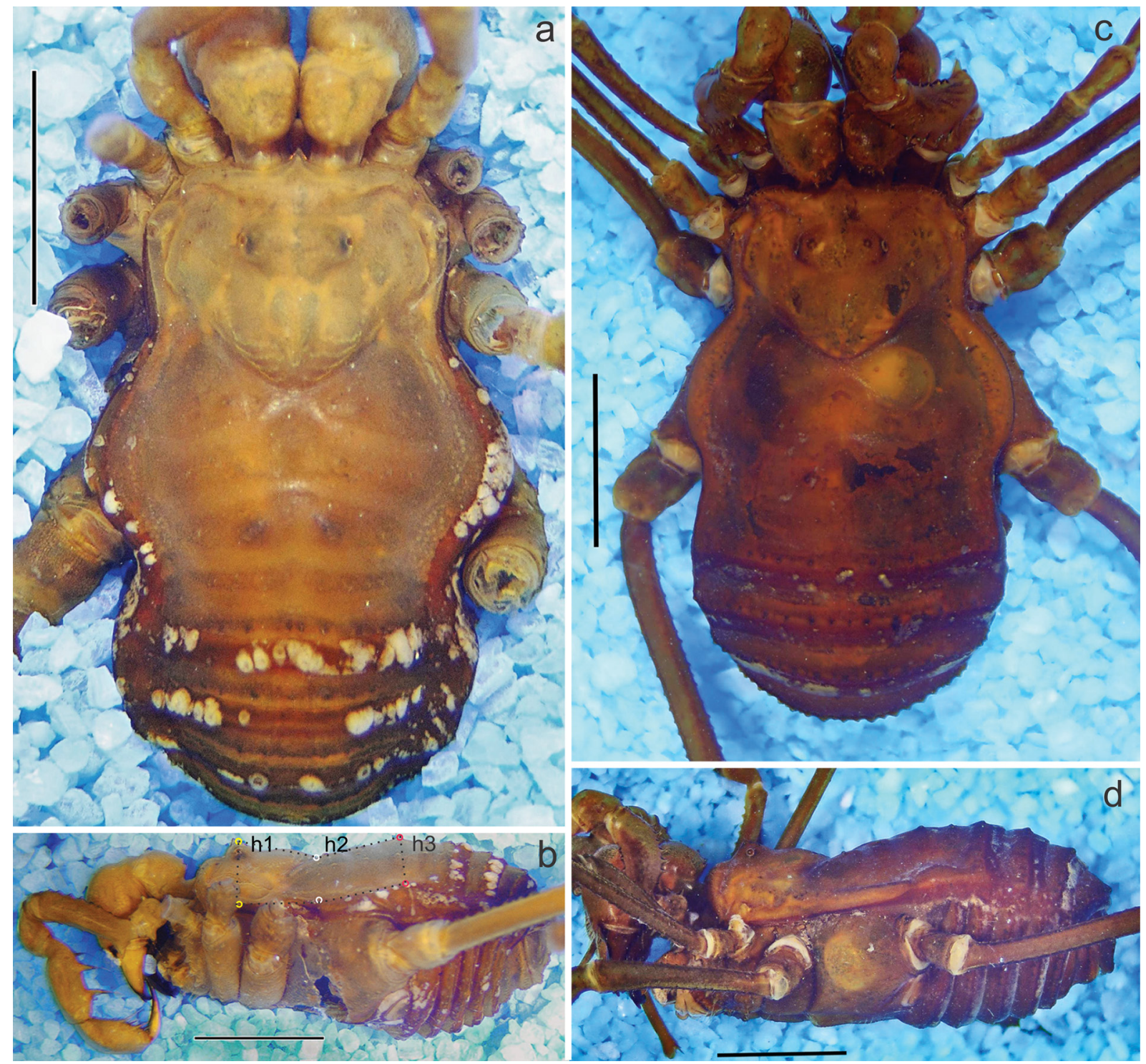

Fig. 2. Phalangodus anacosmetus Gervais, 1842 (syntypes of Allocranaus giganteus Mello-Leitão, 1940, MNRJ 00126). a-b. Ô, juvenile. a. Habitus, dorsal view. b. Habitus, lateral view. c-d. . . c. Habitus, dorsal view. d. Habitus, lateral view. Scale bars $=5 \mathrm{~mm}$. Abbreviations: see Material and methods. 
areas in lateral view (h1/h3 $=1.60$ in Cundinamarca specimens vs $\mathrm{h} 1 / \mathrm{h} 3=1.2$ in Cúcuta specimens) (Figs 1b, 2b); (2) narrower ocularium (ratio wide/length $=1.79$ in Cundinamarca specimens vs 1.46 in Cúcuta specimens); (3) pedipalp of the subadult male from Cúcuta sub cylindrical in lateral view (Fig. 2b) vs dorsally curved from Cundinamarca males. (4) Females from Cundinamarca have a higher ocularium and wider dorsal scutum than Cúcuta's females.

The lack of adult males from Cúcuta in collections makes it is impossible for a comparison of male sexual secondary characters or genital structures.

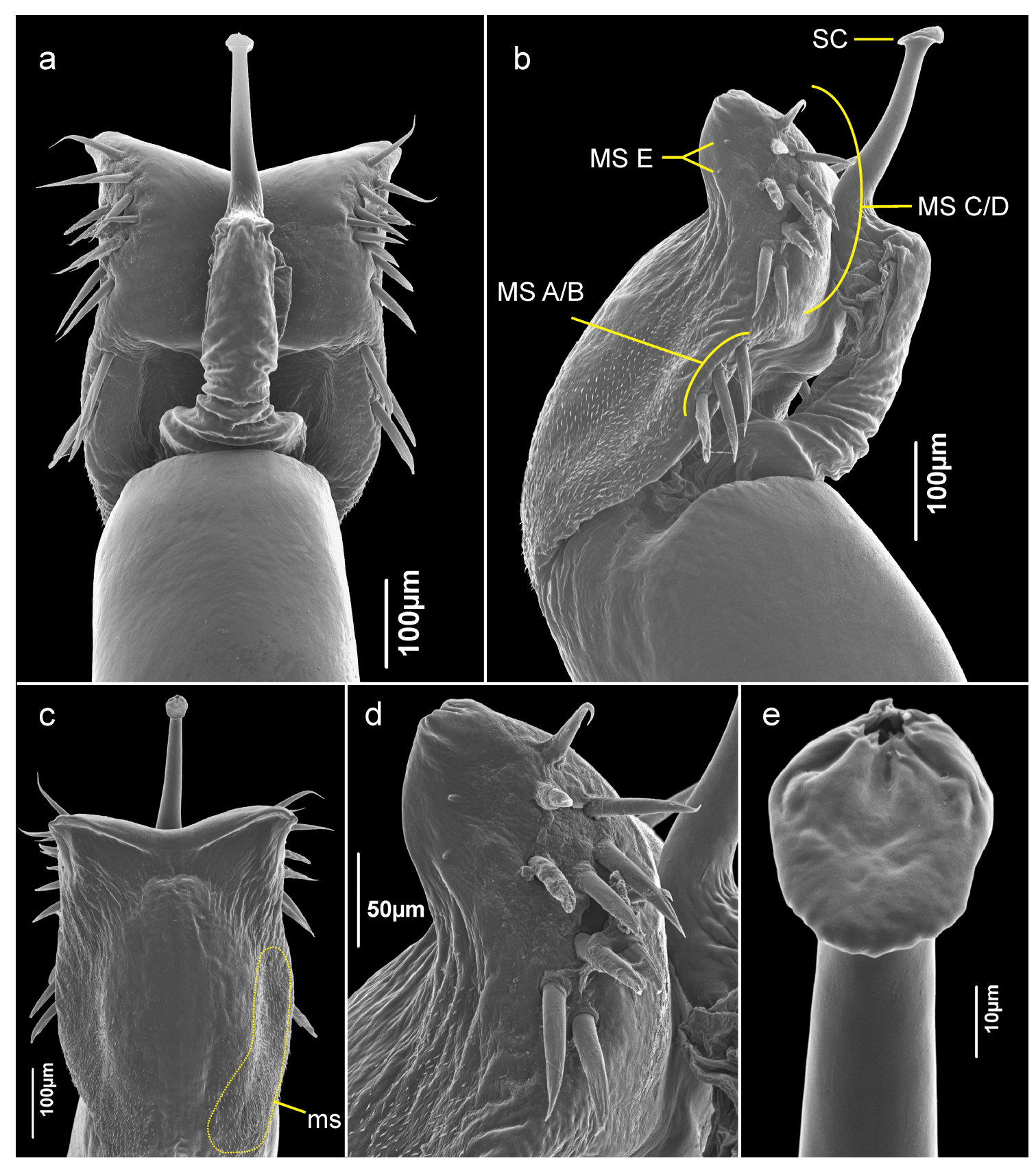

Fig. 3. Phalangodus anacosmetus Gervais, 1842 (ICN-AO-1000), penis distal portion. a. Dorsal view. b. Lateral view. c. Ventral view. d. Detail of MS C, MS E and microsetae, lateral view. e. Stylar caps, ventrodistal view. Abbreviations: see Material and methods. 
On the other hand, there is a considerable gap between the localities of both populations, which indicates an uncommon disjunctive distribution, in neotropical harvestmen (Fig. 18).

Nonetheless, these data suggests the possibility of two species, more detailed studies including males are necessary to taxonomic decisions about identity of Allocranaus giganteus.

\section{Distribution}

Known from Magdalena valley montane forests in southwestern Cundinamarca and Cúcuta, Norte de Santander (Fig. 18) (see remarks above and discussion for details).

Phalangodus briareos sp. nov. urn:Isid:zoobank.org:act:2405BA41-E400-4525-B5C6-4E51A0BD75C9

Figs 4-6, 7a-d, 18-19; Tables 1-2

\section{Diagnosis}

Phalangodus briareos sp. nov. can be distinguished from all other species of the genus (except $P$. cottus sp. nov.) by the distal pair of opposed spines on femur IV of males (Fig. 5c). Phalangodus briareos sp. nov. differs from $P$. cottus sp. nov. by the single median large and curved tubercle on the ventral femur II (Fig. 5e-f); tibia IV without a retrolateral row of spines (Fig. 5d); MS A/B composed by seven pairs of macrosetae (Fig. 6a, c).

\section{Etymology}

Briareos (from Greek Bptó $\rho \varepsilon \omega \varsigma$ ), the vigorous, also called as Aegaeon, one of the three Hecatonchires.

\section{Type material}

\section{Holotype}

COLOMBIA: § (MNRJ 2382), Santander, Zapatoca, Cueva Alsacia, 1737 m, 27 Jan. 1997, Solimary García leg.

\section{Paratypes}

COLOMBIA: 5 $え, 5$ 우 (MNRJ 2163), same data as holotype; $1 \hat{\jmath}$ (ICN-AO-1069), Santander, Zapatoca, Vereda San Javier, farm El Cedral, Reserva Natural Páramo La Floresta, 2250 m, 31 May 2012, J. Díaz leg.; 3 đ̄̃ 1 ㅇ (ICN-AO-1054), Santander, Zapatoca, Vereda Las Flores, cavern La Alsacia, farm Vista Hermosa, 1780 m, 6²7'53.7" N, 73²5'26.1” W, 31 May 2012, J. Díaz leg.

\section{Description}

Male (MNRJ 2382)

Measurements of body and appendage in Table 1 .

Dorsum. Dorsal scutum type alpha (Figs 4a, 5a). Abdominal scutum widest at scutal groove II; lateral borders of dorsal scutum mostly smooth with few minute granules only on the middle region. Carapace mostly smooth, with a group of granules on the anterolateral region. Ocularium high, without median depression, with a paramedian pair of acuminate tubercles (Figs 4a-c, 5a). Integumentary dome of ozopore raised and conspicuous. Abdominal scutum well delimited, divided into four well-marked scutal areas; scutal area I divided into left and right halves by invasion of the scutal area II, with few granules (Fig. 5a); scutal area III with a pair of paramedian acuminate, short, subparallel acuminate tubercles (Figs 4a, c, 5a). Posterior border of scutum straight and with few granules on a row. Free tergites I-III with a row of granules. 


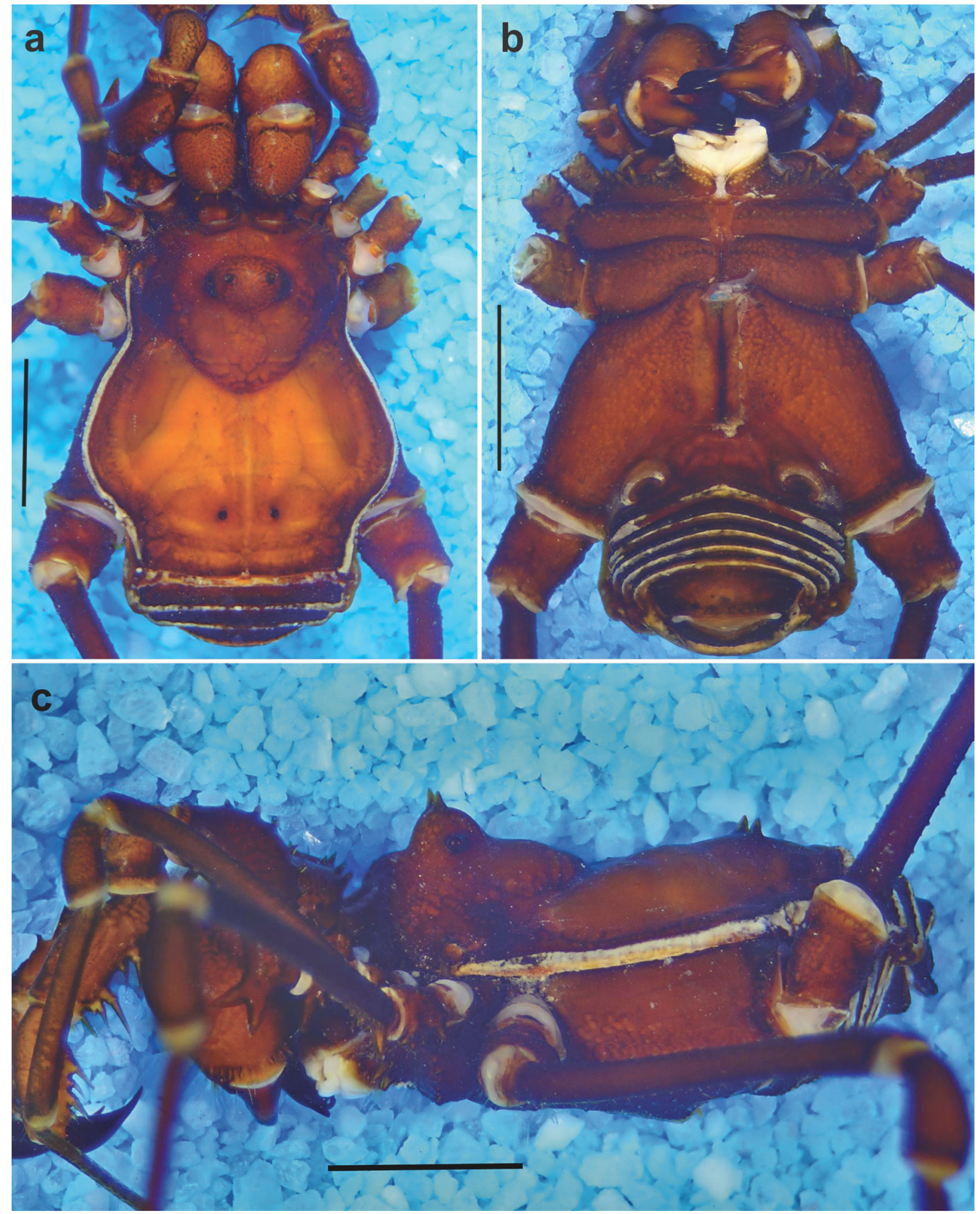

Fig. 4. Phalangodus briareos sp. nov., Ô, holotype (MNRJ 2382). a. Habitus, dorsal view. b. Habitus, ventral view. c. Habitus, lateral view. Scale bars $=5 \mathrm{~mm}$. 
Venter (Fig. 4b). Stigmatic area smooth. Stigmata large, oval and oblique. Coxa I with a row of large tubercles of different size; coxa II longer than coxae I and III, with a median row of low tubercles; coxa III with the posterior border sigmoid, a median row of small tubercles; coxa IV strongly backward, with group of low tubercles close to the stigmatic suture. Free sternites each with a row of small granules.

Chelicera (Figs 4a-b, 5a). Chelicera swollen, bulla with tubercles in the proximal region, one ectal row and one group of dorsomesal tubercles. Fixed finger with a large subproximal tooth and 3 subdistal small teeth. Movable finger with a small subproximal tooth, one large median and one tridentate subdistal lamella. Mesal side of the base of fixed finger and near the base of the movable finger with setiferous tubercles.

Pedipalpus. Trochanter with two large tubercles on a dorsal protuberance; ventrally with two tubercles, the prolateral largest. Femur slightly compressed, dorsally curved and ventrally straight in lateral view, with dorsodistal granules, a dorsal row of large tubercles, ventral surface mostly smooth, with a pair of geminated large tubercles. Mesal and ectal faces without large tubercles (Fig. 5b). Patella short (ratio $\mathrm{FePp} / \mathrm{PaPp}=2.6$ ), cylindrical and curved, with few small dorsodistal granules. Tibia ventrally flattened and dorsally curved; tibial setation: mesal IiII $(3>1>4>2)$, ectal Iili $(1>3>4>2)$ (the two distal

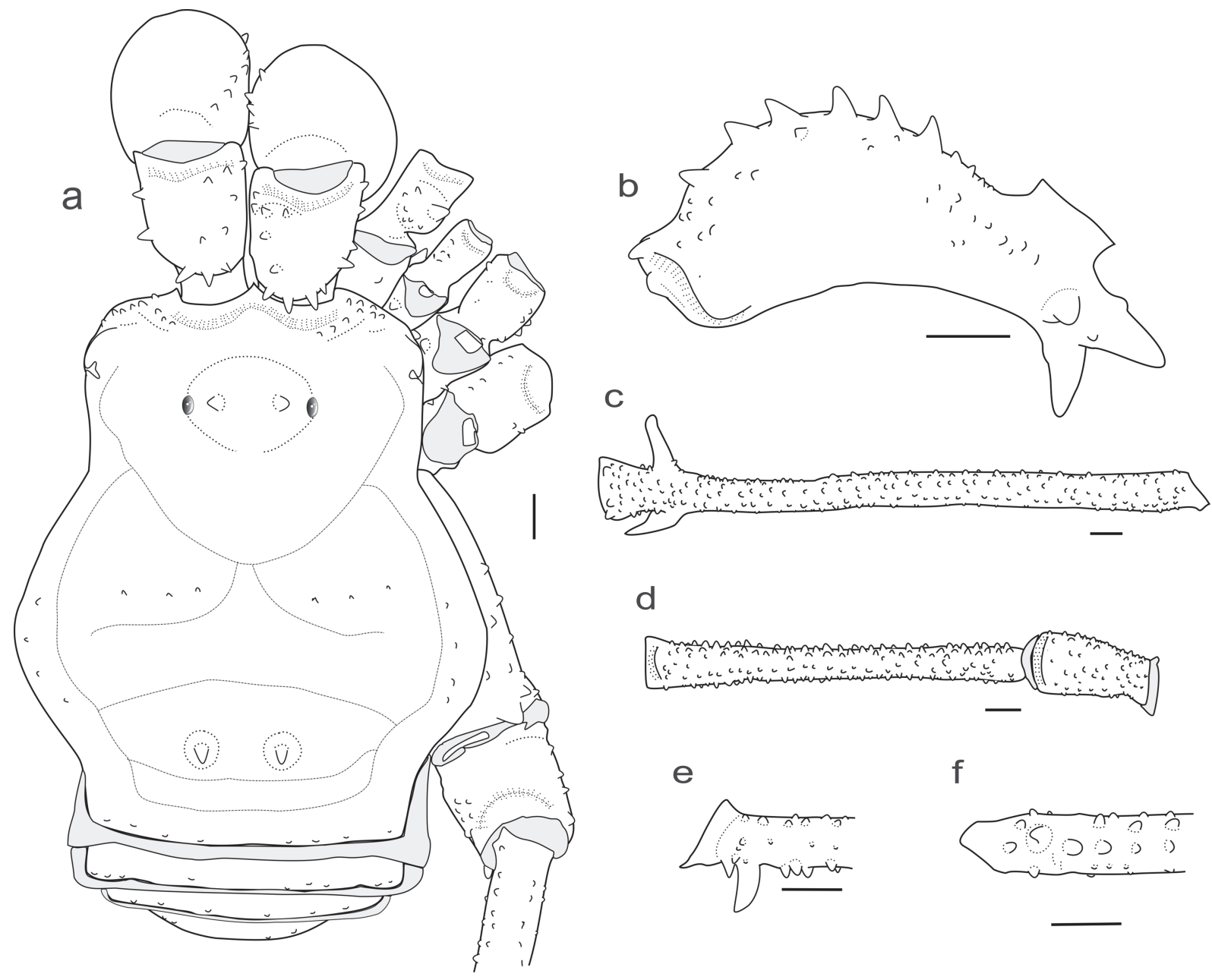

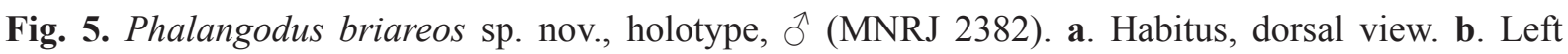
pedipalpal femur, ectal view. c. Right femur IV, dorsal view. d. Right patella and tibia IV, dorsal view. e-f. Right femur II, proximal portion. e. Retrolateral view. f. Ventral view. Scale bars $=1 \mathrm{~mm}$. 


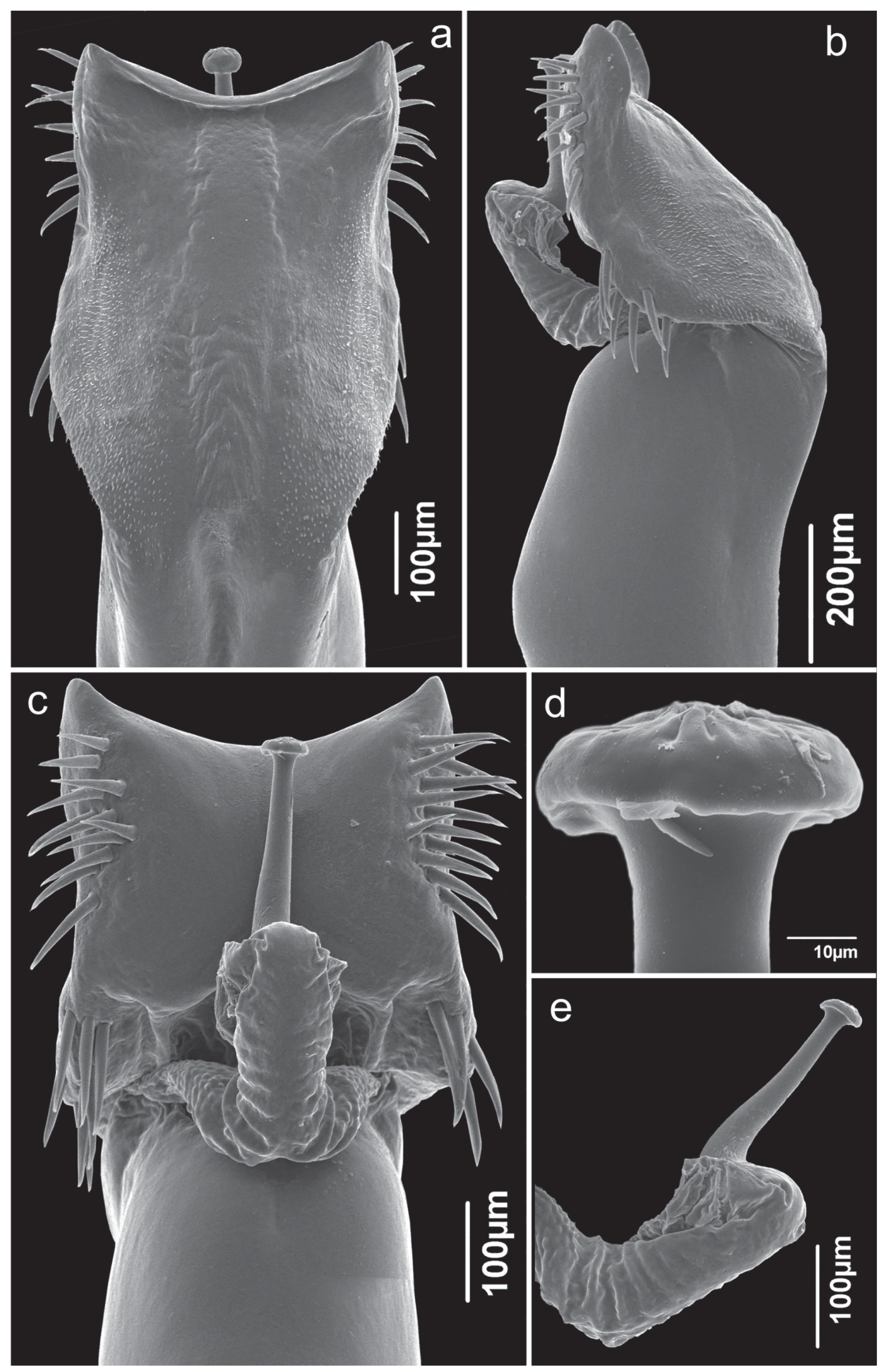

Fig. 6. Phalangodus briareos sp. nov., holotype, $\widehat{\jmath}$ (MNRJ 2382), penis distal portion. a. Ventral view. b. Lateral view. c. Dorsal view. d. Stylar caps, dorsal view. e. Stylus, lateral view. 
VILLARREAL O. \& GARCÍA M.A.F., Four new species of Phalangodus from Colombia

Table 1. Phalangodus briareos sp. nov., measurements of body and appendage, in millimeters.

\begin{tabular}{|c|c|c|c|c|}
\hline & \multirow{4}{*}{$\begin{array}{c}\text { Holotype } \\
\text { (MNRJ 2382) } \\
\widehat{\partial}\end{array}$} & \multicolumn{3}{|c|}{ Paratypes } \\
\hline & & \multirow{3}{*}{$\begin{array}{c}\text { (ICNAO1069) } \\
\precsim(\mathbf{n}=\mathbf{1})\end{array}$} & \multirow{2}{*}{\multicolumn{2}{|c|}{$\begin{array}{c}\text { (MNRJ 2163) } \\
\varnothing(n=4)\end{array}$}} \\
\hline & & & & \\
\hline & & & Min. & Max. \\
\hline DSL & 12.4 & 10.6 & 10.8 & 11.6 \\
\hline CL & 6.0 & 5.0 & 4.9 & 5.3 \\
\hline $\mathbf{C W}$ & 7.4 & 6.4 & 6.4 & 6.6 \\
\hline $\mathbf{A L}$ & 6.4 & 5.6 & 5.6 & 6.6 \\
\hline AW & 10.4 & 9.0 & 8.9 & 9.3 \\
\hline IOD & 2.2 & 1.8 & 1.8 & 2.1 \\
\hline BaCh & 2.6 & 2.4 & 2.0 & 2.5 \\
\hline FePp & 4.8 & 4.4 & 3.3 & 4.7 \\
\hline PaPp & 1.8 & 2.2 & 1.8 & 2.2 \\
\hline TiPp & 4.0 & 2.8 & 2.9 & 3.2 \\
\hline $\mathrm{Fe} I$ & 7.2 & 6.2 & 6.1 & 6.4 \\
\hline Fe II & 15.4 & 12.6 & 12.4 & 13.2 \\
\hline Fe III & 12.4 & 10.0 & 10.0 & 10.6 \\
\hline Fe IV & 17.8 & 13.2 & 13.0 & 13.6 \\
\hline Ti I & 5.4 & 5.0 & 4.2 & 4.6 \\
\hline Ti II & 12.4 & 10.4 & 10.1 & 10.6 \\
\hline Ti III & 7.2 & 6.8 & 5.8 & 6.3 \\
\hline Ti IV & 11.0 & 10.4 & 8.6 & 9.2 \\
\hline
\end{tabular}

ones fused at base). Tarsus with similar shape of tibia; tarsal setation: mesal iIi $(2>1>3)$, ectal IIii $(2>$ $1>3=4$ ). Claw basally swollen.

LEGS. Coxa I with two dorsal tubercles, the retrolateral one reaching the dorsal tubercle of the coxa II which has one prolateral and two retrolateral tubercles; III unarmed; IV with the prolateral face slightly granulate and with one dorsodistal domed large tubercle. Trochanter I-III unarmed; trochanter I-II with a large ventral, two ventrodistal tubercles and some prolateral granules; trochanter III with a prolateral row of granules and a slight retrolateral expansion; trochanter IV proximally swollen (Fig. 4a-b) with a ventrodistal retrolateral tubercle and many granules irregularly distributed. Femora I-III straight and with longitudinal rows of granules; femur II with a large proximal tubercle on the ventrolateral side (Fig. 5e-f); femur IV sub-straight, granulate, with a distal pair of large spiniform tubercles, one pointing retrolaterally and the other, prolaterally (Fig. 5c). Tibia I-IV straight and densely granulate, unarmed (Fig. 5d). Claws III-IV smooth. Ratio Fe IV/scutum $=1.44$. Tarsal counts in Table 2.

GenitaLia. Ventral plate (VP) subrectangular, with mid-constriction, the basal lobes curved and laterodistal border slightly projected, anterior border concave, ventrally with a well-marked longitudinal median elevation (Fig. 6a). Proximal ventral surface of VP with two inverted lung-shaped fields of small, needle-like microsetae (Fig. 6a-b). MS A/B forming a proximal group of seven pairs of large, acuminate and cylindrical setae, pointing towards to the base of the penis trunk; MS C composed by 11-12 pairs of 

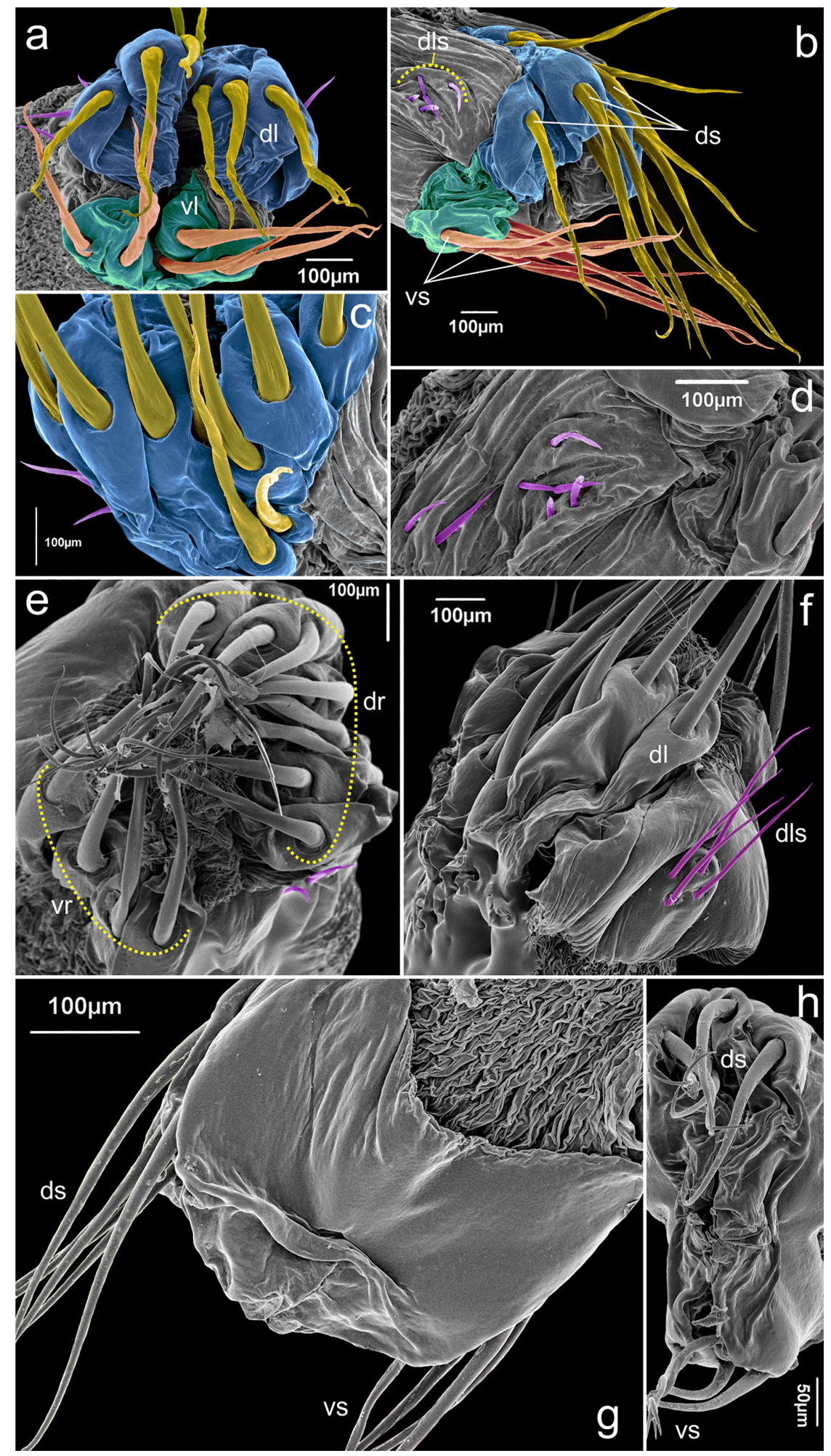

Fig. 7. Distal portion of the ovipositor, colorized to show structures as defined here. See text for more details. - a-d. Phalangodus briareos sp. nov. (MNRJ 2163). a. Distal view. b. Latero-distal view. c. Dorso-distal view. d. Detail of dorso-lateral group of microsetae. - e-f. Phalangodus gyes sp. nov. (MNRJ 17907). e. Distal view. f. Latero-dorsal view. - g-h. Phareicranaus hermosa Pinto-da-Rocha \& Kury, 2003 (UFMG 9223). g. Lateral view. h. Distal view. Abbreviations: see Material and methods. 
Table 2. Tarsal formula of Phalangodus briareos sp. nov. (numbers in parentheses are the number of distitarsomeres).

\begin{tabular}{ccccc}
\hline & Ta I & Ta II & Ta III & Ta IV \\
\hline MNRJ 2382 $⿱ 亠$ & $9(3)-9(3)$ & $16(3)-13(3)$ & $8-8$ & $9-9$ \\
ICNAO1069 $\hat{0}$ & $9(3)-9(3)$ & $16(3)-14(3)$ & $8-8$ & $9-9$ \\
\hline
\end{tabular}

setae with similar shape to MS A/B, MS D if present, indistinguishable from MS C, grouped in a distal group (here called MS C/D) (Fig. 6b-c). Two pairs of very small MS E, placed on latero-distal flange (Fig. 6b). Glans sac columnar elongate, with proximal folds and circular small protuberances on the base (Fig. 6b-c, e). Stylus straight, without processes. Stylar caps ring-shaped, without lateral or ventral projections (Fig. 6d-e).

Coloration (in alcohol) (Fig. 4). Carapace tomato red 40, reticulated in the posterior region and ocularium. Abdominal scutum sunflower 66, with the scutal area III and lateral of scutal area I russet orange 51. Lateral and posterior borders of dorsal scutum, free tergites and spines of scutal area III red mahogany 41. Pedipalps, coxae I-IV, stigmatic area and trochanters dark lacquer red reticulated. Chelicerae tomato red 36 reticulated. Tip of cheliceral teeth red plum 260.

Female (MNRJ 2163)

Similar to male, differing by: ocularium slightly narrower; carapace larger; coda wider; tubercles of area III higher. Chelicerae with movable finger thinner. Pedipalpal femur lower and thinner in lateral view, with ventroproximal smaller tubercles, pedipalpal claw not swollen. Stigmatic area shorter, without the groups of granules anteriorly to stigmata. Genital operculum wider. Trochanters III-IV narrower; femur III without ventroproximal large tubercle; femur IV slightly curved proximally, thinner, without retrolateral distal spine and with a reduced prolateral tubercle; tibia IV with retrolateral granules smaller.

Ovipositor (Fig. 7a-d): Dorsal lobes (dl) and ventral lobes (vl) rounded, with four and three pairs of large, acuminated, single-tipped setae respectively. Dl with three pairs of dorsal setae (ds) distally located and one pair basally located (Fig. 7c). Lateral region of the ovipositor with one dorso-lateral group of seven short setae (dls), two of them rounded (Fig. 7b, d).

\section{Distribution}

Known only from the type locality (Figs 18-19).

Phalangodus cottus sp. nov. urn:1sid:zoobank.org:act:A335733E-2181-437A-8B1F-CA78015F2B9C

Figs 8a-b, 9-10, 18; Tables 3-4

\section{Diagnosis}

Phalangodus cottus sp. nov. can be distinguished from all other species of the genus (except $P$. briareos sp. nov.) by the presence of a distal pair of opposed spines on femur IV of the males, one prolateral and one retrolateral (Fig. 9f, h). P. cottus sp. nov. differs from P. briareos sp. nov. by the ventro-proximal two short rows of large tubercles on femur II in males (Fig. 9d-e); tibia IV with a retrolateral row of spines (Fig. 9g); MS A/ composed by two pairs of macrosetae (Fig. 10a-b).

\section{Etymology}

Cottus (from the Greek Kó $\tau$ o $\varsigma$ ), the striker, one of the three Hecatonchires. 


\section{Type material}

\section{Holotype}

COLOMBIA: $\widehat{\overbrace{}}$ (MNRJ 8654), Meta, Villavicencio, farm La Loma, Pt. 1, Aug. 2006, Alessandro Giupponi leg.

\section{Paratypes}

COLOMBIA: 1 ô, 3 + $q$ (MNRJ 17942), same data as holotype.

\section{Description}

Male (MNRJ 8654)

Measurements of body and appendage in Table 3.

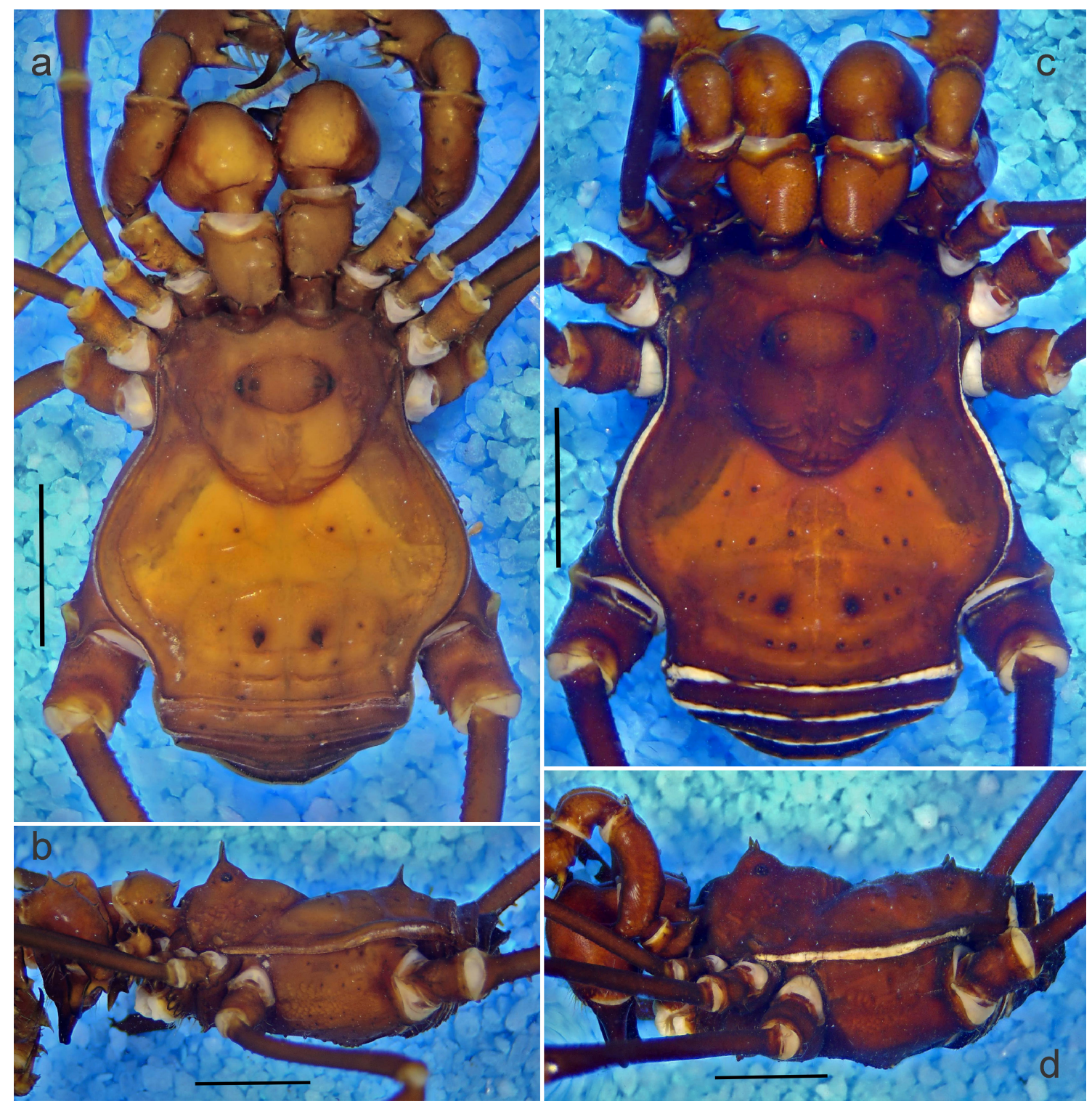

Fig. 8. - a-b. Phalangodus cottus sp. nov., holotpye, § (MNRJ 8654). a. Habitus, dorsal view. b. Habitus, lateral view. -c-d. Phalangodus gyes sp. nov., holotype, $\widehat{\sigma}$ (MNRJ 8655). c. Habitus, dorsal view. d. Habitus, lateral view. Scale bars $=5 \mathrm{~mm}$. 
Table 3. Phalangodus cottus sp. nov., measurements of body and appendage, in millimeters.

\begin{tabular}{|c|c|c|c|c|}
\hline & \multirow{3}{*}{$\begin{array}{c}\text { Holotype } \\
\text { (MNRJ 8654) } \\
\delta\end{array}$} & \multicolumn{3}{|c|}{$\begin{array}{c}\text { Paratypes } \\
\text { (MNRJ 17942) }\end{array}$} \\
\hline & & \multirow{2}{*}{$\widehat{\partial}(\mathbf{n}=\mathbf{1})$} & \multicolumn{2}{|c|}{$q(\mathbf{n}=\mathbf{3})$} \\
\hline & & & Min. & Max. \\
\hline DSL & 12.2 & 12.4 & 10.0 & 11.2 \\
\hline $\mathbf{C L}$ & 5.8 & 6.0 & 4.6 & 5.4 \\
\hline CW & 7.4 & 7.2 & 6.6 & 7.0 \\
\hline $\mathbf{A L}$ & 6.4 & 6.4 & 5.4 & 5.8 \\
\hline AW & 11.4 & 11.2 & 9.8 & 10.2 \\
\hline IOD & 2.6 & 2.4 & 2.0 & 2.2 \\
\hline $\mathrm{BaCh}$ & 2.4 & 2.2 & 2.0 & 2.2 \\
\hline FePp & 4.2 & 4.4 & 3.4 & 4.0 \\
\hline PaPp & 2.4 & 2.0 & 1.8 & 2.4 \\
\hline TiPp & 3.0 & 2.8 & 2.8 & 3.0 \\
\hline Fe I & 6.8 & 6.2 & 5.2 & 5.8 \\
\hline Fe II & 13.0 & 12.2 & 11.2 & 12.4 \\
\hline Fe III & 11.6 & 10.8 & 9.2 & 10.0 \\
\hline Fe IV & 14.4 & 15.0 & 11.6 & 12.8 \\
\hline Ti I & 5.2 & 5.0 & 4.2 & 4.8 \\
\hline Ti II & 11.0 & 11.0 & 9.4 & 9.8 \\
\hline Ti III & 6.6 & 6.0 & 5.4 & 5.6 \\
\hline Ti IV & 9.0 & 9.0 & 7.4 & 7.8 \\
\hline
\end{tabular}

Dorsum. Dorsal scutum type alpha (Figs 8a, 9a). Abdominal scutum widest at scutal groove III level; lateral borders of dorsal scutum smooth. Carapace mostly smooth, with a group of small tubercles on the anterolateral region. Ocularium high, without median depression, with a paramedian pair of large, acuminate tubercles (Figs 8a-b, 9a). Integumentary dome of ozopore raised and conspicuous. Abdominal scutum well delimited, divided into four well-marked scutal areas: scutal area I divided into left and right halves by invasion of the scutal area II, with a pair of small granules on each side; scutal area III with a pair of paramedian acuminate high subparallel tubercles (Figs 8a, 9a). Posterior border of scutum straight, with only a pair of paramedian tubercles (Figs 8a, 9a), unarmed. Free tergites I-III with granules sparsely distributed, tergite II with a paramedian pair of large granules.

VENTER. Stigmatic area smooth. Stigmata large, oval and oblique. Coxa I with a row of large tubercles of different size; coxa II longer than coxae I and III, with a median row of large tubercles; coxa III with a median row of small tubercles and with the posterior border sigmoid; IV strongly backward, with some dark tubercles sparsely distributed and a group close to the stigmatic area. Free sternites with a row of small dark tubercles.

Chelicera (Figs 8a, 9a). Chelicera swollen, bulla with curved tubercles on its proximal border and ectal face, and a group of mesodorsal tubercles. Hand with a longitudinal row of downward curved acuminate tubercles (distal largest). Fixed finger with a proximal conical tooth and a subdistal laminar tooth. Movable finger with a proximal rounded tooth, a median conical tooth and four low subdistal teeth. With many setiferous tubercles on the base of fixed finger . 
Table 4. Tarsal formula of Phalangodus cottus sp. nov. (numbers in parentheses are the number of distitarsomeres).

\begin{tabular}{ccccc}
\hline & Ta I & Ta II & Ta III & Ta IV \\
\hline MNRJ 08654 o & $8(3)-8(3)$ & $16(3)-12(3)$ & $7-7$ & $8-8$ \\
MNRJ 17942 $⿱ 亠$ & $8(3)-8(3)$ & $16(3)-12(3)$ & $7-7$ & $?-8$ \\
MNRJ 17942 $q$ & $8(3)-8(3)$ & $14(3)-12(3)$ & $7-7$ & $8-8$ \\
MNRJ 17942 $q$ & $8(3)-8(3)$ & $14(3)-15(3)$ & $7-7$ & $8-8$ \\
MNRJ 17942 $q$ & $8(3)-8(3)$ & $14(3)-15(3)$ & $7-7$ & $8-8$ \\
\hline
\end{tabular}

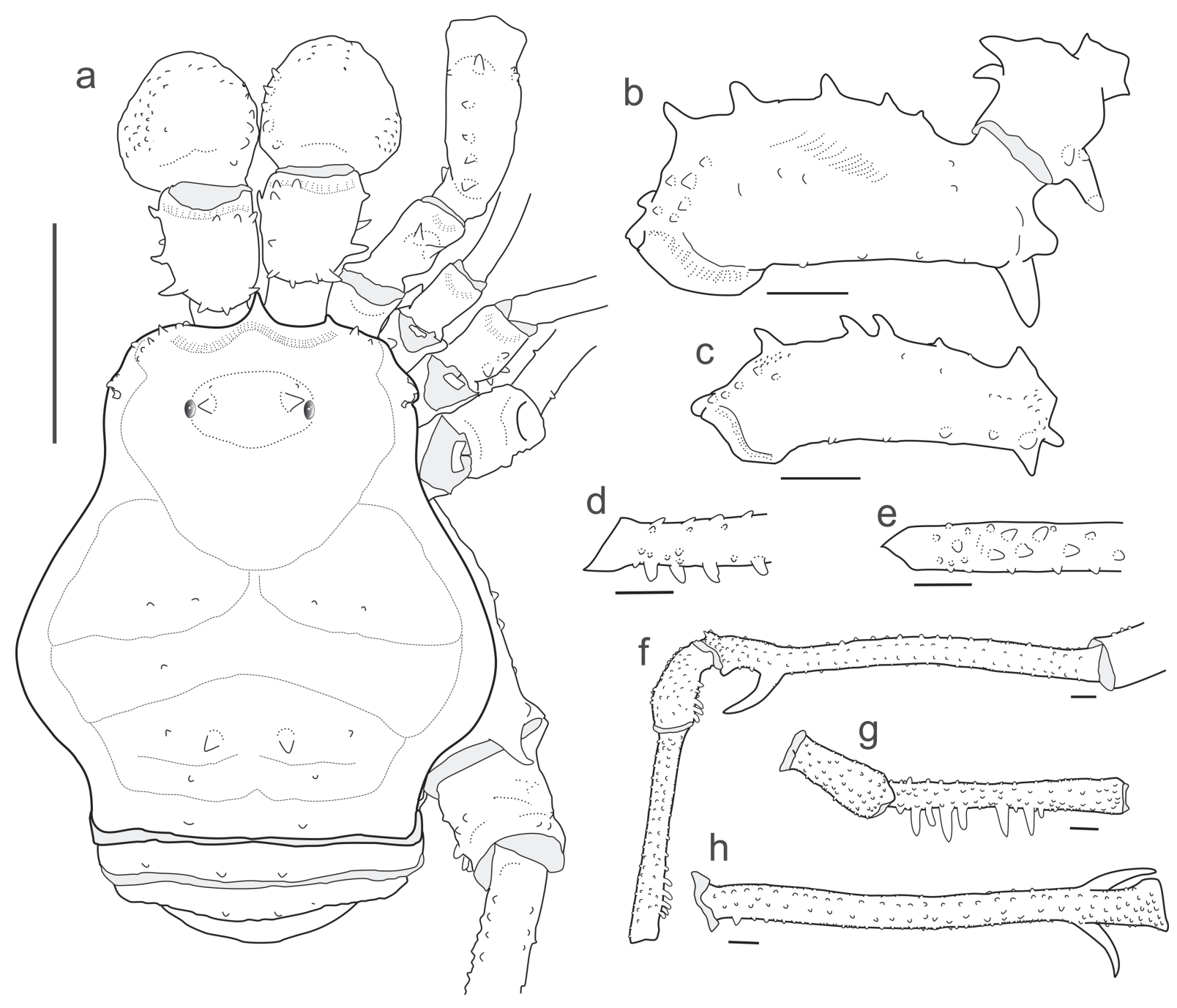

Fig. 9. Phalangodus cottus sp. nov. a-b, d-h. Holotype, đ̊ (MNRJ 8654). c. Paratype, $q$ (MNRJ 17942). a. Habitus, dorsal view. b. Left pedipalp trochanter and femur, ectal view. c. left pedipalpal femur, mesal view. d-e. Right femur II, proximal portion. d. Retrolateral view. e. Ventral view. f-h. Right leg IV. f. Femur, patella and tibia, prolateral view. g. Patella and tibia, dorsal view. h. Femur, dorsal view. Scale bars: $\mathrm{a}=5 \mathrm{~mm}$; $\mathrm{b}-\mathrm{h}=1 \mathrm{~mm}$. 
Pedipalpus. Trochanter with two-three tubercles on a dorsal protuberance, ventrally with two tubercles, the median largest and curved. Femur (Fig. 9b) slightly compressed, dorsally curved and ventrally straight in lateral view, with a dorsal row of four-five forward curved tubercles, ventrally with a pair of geminated large tubercles. Patella short (ratio FePp/PaPp $=1.75$ ), cylindrical and curved with small dorsal granules. Tibia dorsally with scarce and small granules, ventrally smooth with two longitudinal medial row of small granules; tibial setation: ectal (IiIi) $(3>1>4>2)$ and accessory distal tubercle (the last ones St share a common base), mesal (IiIi) $(3>1>4>2)$. Tarsus ectally (Iili) $(3>1>2=4)$ and mesally (IIi) $(1=2>3)$, the mesal and ectal faces with a row of proximal tubercles at the base of the St forming a crenulate lamella. Claw not swollen.

Legs. Coxa I with one dorsal tubercle; II with a dorsal tubercle; III unarmed; IV with few prolateral tubercles and one dorsodistal, prolateral, curved, acuminated tubercle. Trochanters I-IV unarmed; ventrally, I with three tubercles (one medial and two distal), and one proximal retrolateral tubercle; II with retrolateral group of tubercles and one retrolateral ventral, large, acuminate tubercle; III enlarged in the middle, dorsally unarmed and ventrally with a median large tubercle and four retrolateral tubercles; IV proximally enlarged (Fig. 8a), dorsally smooth, with few ventral, small, dark granules and two retrolateral, distal, large tubercles. Femora I-III straight, with longitudinal rows of granules; femur II with two short rows of large ventral tubercles (Fig. 9d, e); femur III with a retrolateral, ventral proximal row of large tubercles; femur IV slightly curved, densely granulate, with a ventral subdistal pair of large spiniform tubercles pointing opposite directions, the retrolateral one oblique (Fig. 9h) and the prolateral one hook-like shaped (Fig. 9f). With one retrolateral proximal tubercle (Fig. 9f). Patella IV ventrally with prolateral row of tubercles (Fig. 9f). Tibiae III-IV straight and densely granulate; tibia III with a retroventral row of tubercles; tibia IV with a retrolateral row of large, spiniform tubercles, and two distal ventral rows of large tubercles. (Fig. 9f, g). Metatarsus IV with pale ring markings. Claws III-IV smooth. Ratio Fe IV/scutum =1.18. Tarsal counts in Table 4.

GENITALIA (MNRJ 17942). Ventral plate (VP) subrectangular, with mid-constriction, the proximal lobes curved and laterodistal border sligthly projected, anterior border with smooth concavity (Fig. 10b-c). Ventral surface of VP with two inverted? lung-shaped fields of minute and needle-like microsetae (Fig. 10c). MS A/Bforming a proximal group of two pairs of large, acuminate and cylindrical setae, pointing towards to the base of the penis trunk; MS C/D composed by 11 pairs of setae with similar shape to MS A/B. (Fig. 10a-b, e). Two pairs of very small MS E located on latero-distal flange (Fig. 10a). Glans sac columnar elongate, with proximal folds. Stylus straight, without processes (Fig. 10a-b, e). Stylar caps ring-shaped, without lateral or ventral projections (Fig. 10d-e).

Coloration (in alcohol). Carapace tangerine 50 with terra cotta 55 in lateral areas and ocularium. Abdominal scutum sunflower 68, with tubercles and spines red mahogany 41 . Free tergites pastel orange 53. Legs, pedipalps and basiquelicerites tangerine 50. Claw of pedipalps, and ventral tubercles of the coxae dark brown 59. Lateral and posterior border of dorsal scutum, free tergites and spines of scutal area III red mahogany 41. Pedipalps, coxae I-IV, stigmatic area and trochanters dark lacquer red reticulated. Chelicerae tomato red 36 reticulated. Tip of cheliceral teeth red plum 260.

Female (MNRJ 17942)

Similar to male, differing by: ocularium slightly narrower; carapace slightly larger; coda wider; chelicerae with movable finger thinner; pedipalpal femur, patella and tibia thinner, with ventroproximal tubercles smaller; spines of ocularium and tubercles of area III higher; stigmatic area shorter, without the groups of granules anteriorly to stigmata; genital operculum wider; trochanters III-IV narrower, trochanter IV without retrolateral tubercles; femur IV thinner, without proximal tubercle; tibia IV without retrolateral row of granules and the ventral rows with smaller tubercles; tergite II with a pair of large paramedian tubercles. 
Ovipositor. $\mathrm{dl}$ and $\mathrm{vl}$ rounded with five and two pairs of large, acuminated, single-tipped setae respectively. Dl with five pairs of ds, one of them basally located and the lateral region of the ovipositor with two pairs of dorso-lateral group of short setae.

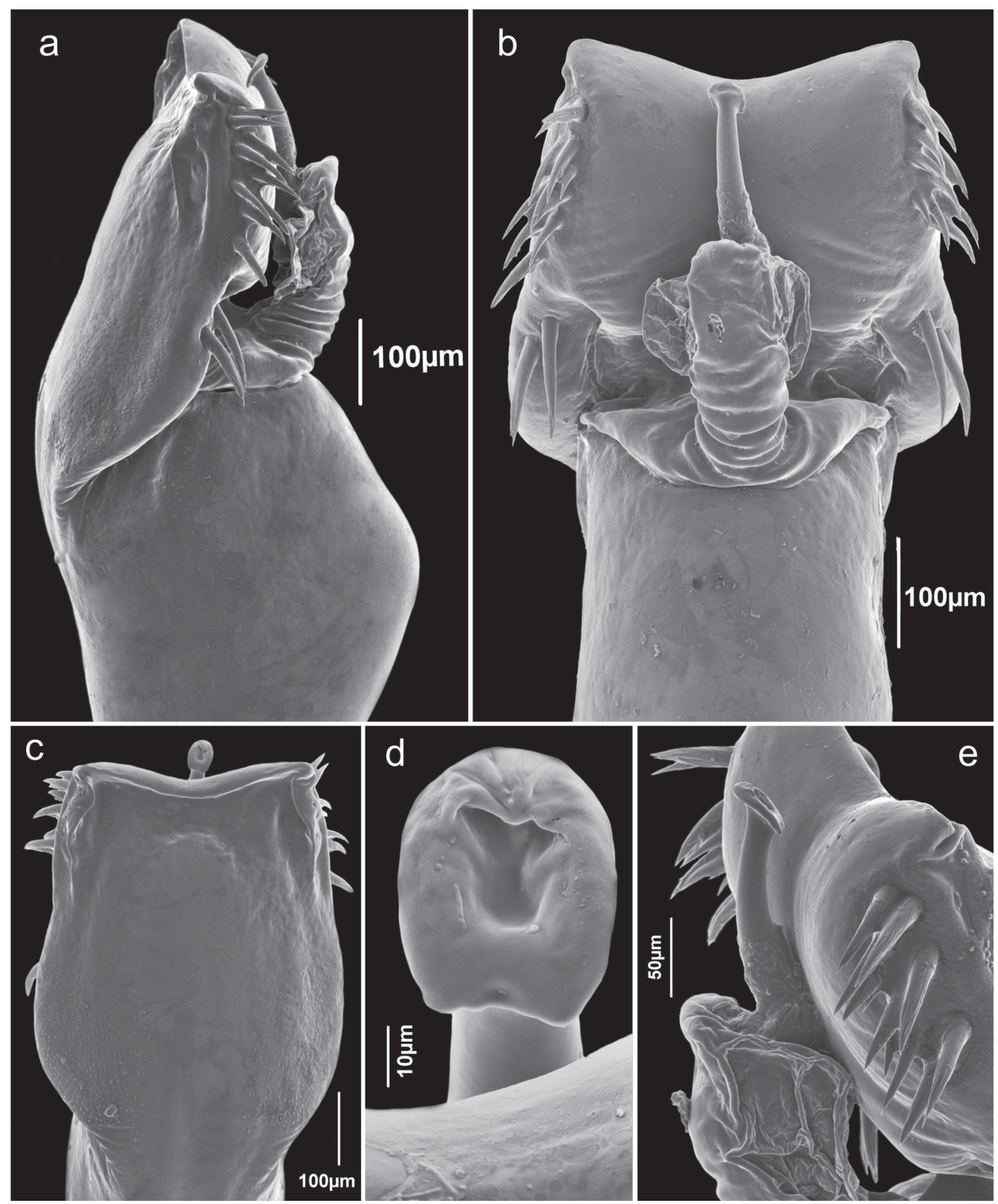

Fig. 10. Phalangodus cottus sp. nov., paratype, $\widehat{\jmath}$ (MNRJ 17942), penis distal portion. a. Lateral view. b. Dorsal view. c. Ventral view. d. Stylar caps, ventrodistal view. e. Distal portion of the ventral plate and stylus, dorsolateral view. 


\title{
Distribution
}

Known only from the type locality (Fig. 18).

\author{
Phalangodus gyes sp. nov. \\ urn:1sid:zoobank.org:act:CA85FCA3-D4A8-4B99-8115-E852A08048E5 \\ Figs $7 \mathrm{e}-\mathrm{f}, 8 \mathrm{c}-\mathrm{d}, 11-12$, 18; Tables 5-6
}

\section{Diagnosis}

Phalangodus gyes sp. nov. can be distinguished from all other species with a high ocularium by the combination of the following characters: unarmed (absence of distal spines or large tubercles on) males femur IV and males tibia IV with a prolateral proximal group of large tubercles (Fig. 11d).

\section{Etymology}

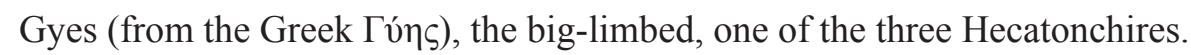

\section{Type material}

\section{Holotype}

COLOMBIA: §̊ (MNRJ 8655), Tolima, Ibagué, Pt. 6, 3 Aug. 2006, Alessandro Giupponi leg.

\section{Paratypes}

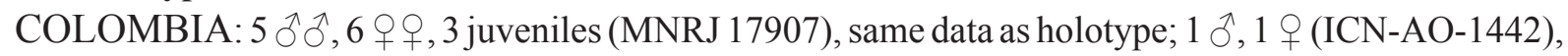
same data as holotype; 1 ग, 1 (ICN-AO-519), Tolima, Ibagué, Vereda Ambala Alta, Reserva Forestal de Bellavista, 1880 m, 18 Aug. 2008, manual collection at night with UV. light, J. Ochoa and E. Florez leg.

\section{Description}

\section{Male (MNRJ 8655)}

Measurements of body and appendage in Table 5.

Dorsum. Dorsal scutum type alpha (Figs 8c, 11a). Abdominal scutum wider at scutal groove II; lateral borders of dorsal scutum smooth. Carapace mostly smooth, with a row of granules on the anterolateral region. Ocularium high, without median depression, with a paramedian pair of short and acuminate tubercles (Fig. 8c-d). Integumentary dome of ozopore raised and conspicuous. Abdominal scutum well delimited, divided into four well-marked scutal areas: scutal area I divided into left and right halves by invasion of the scutal area II, with a pair of small dark granules (Figs 8c, 11a); scutal area II with a transverse row of six dark granules; scutal area III with a pair of paramedian conical, dark and short tubercles (Fig. 8d). Posterior border of scutum straight, with a row of seven low dark tubercles (Fig. 8c). Free tergites I-III each with a row of few dark granules.

Venter. Stigmatic area smooth. Stigmata large, oval and slightly oblique. Coxa I densely covered with irregular rows of tubercles; coxa II longer than coxae I and III, with two rows of small tubercles; coxa III with a median row of tubercles and few distal small tubercles sparsely distributed and with the posterior border sigmoid; coxa IV strongly backward, with some granules sparsely distributed and one group of tubercles on a prominence close to the stigmatic area. Free sternites each with a row of small granules.

Chelicera (Fig. 11a). Chelicera swollen, bulla with an ectal row of four-five tubercles curved anteriorly and a group of dorsodistal mesal tubercles. Hand with small frontal tubercles. Fixed finger with four conical teeth decreasing in size subdistally. Movable finger with a proximal wide lamella, a median truncate tooth and two fused subdistal teeth. 
Table 5. Phalangodus gyes sp. nov., measurements of body and appendage, in millimeters.

\begin{tabular}{|c|c|c|c|c|c|}
\hline & \multirow{3}{*}{$\begin{array}{c}\text { Holotype } \\
\text { (MNRJ 8655) } \\
ð\end{array}$} & \multicolumn{4}{|c|}{$\begin{array}{c}\text { Paratypes } \\
\text { (MNRJ 17907) }\end{array}$} \\
\hline & & \multicolumn{2}{|c|}{$\hat{\partial}(\mathbf{n}=\mathbf{6})$} & \multicolumn{2}{|c|}{$\uparrow(\mathbf{n}=7)$} \\
\hline & & Min. & Max. & Min. & Max. \\
\hline DSL & 13.4 & 10.8 & 13.4 & 11.4 & 12.0 \\
\hline CL & 6.8 & 5.2 & 6.8 & 5.0 & 5.8 \\
\hline $\mathrm{CW}$ & 9.0 & 7.6 & 9.0 & 7.0 & 7.8 \\
\hline $\mathbf{A L}$ & 6.6 & 5.6 & 6.6 & 6.0 & 6.4 \\
\hline AW & 11.8 & 9.6 & 12.2 & 9.4 & 10.0 \\
\hline IOD & 2.4 & 2.4 & 3.0 & 2.0 & 2.4 \\
\hline $\mathrm{BaCh}$ & 2.6 & 2.4 & 2.8 & 2.0 & 2.4 \\
\hline FePp & 5.4 & 4.4 & 5.2 & 3.4 & 4.6 \\
\hline PaPp & 2.0 & 1.8 & 2.2 & 1.8 & 2.2 \\
\hline TiPp & 2.8 & 2.6 & 3.0 & 3.0 & 4.0 \\
\hline Fe I & 9.2 & 7.8 & 9.8 & 6.0 & 6.6 \\
\hline Fe II & 25.0 & 18.0 & 28.6 & 12.0 & 13.8 \\
\hline Fe III & 12.2 & 11.0 & 13.8 & 9.0 & 9.6 \\
\hline Fe IV & 15.0 & 13.8 & 18.0 & 11.4 & 12.2 \\
\hline Ti I & 7.6 & 5.8 & 8.2 & 4.6 & 5.6 \\
\hline Ti II & 23.2 & 17.2 & 25.6 & 10.6 & 11.6 \\
\hline Ti III & 9.0 & 7.4 & 9.4 & 6.0 & 6.4 \\
\hline Ti IV & 11.0 & 10.0 & 12.6 & 8.4 & 8.6 \\
\hline
\end{tabular}

Pedipalpus. Trochanter with two dorsal tubercles on a dorsal protuberance, ventrally with two subequal tubercles. Femur (Fig. 11b) slightly compressed, dorsally curved and ventrally straight in lateral view. With a dorsal row of four-five forward curved acuminate tubercles, ventrally with a proximal pair of geminated large tubercles. Patella short (ratio FePp/ $\mathrm{PaPp}=2.7$ ), cylindrical and very curved, with small dorsal granules. Tibia dorsally with two irregular rows of minute granules, ventrally unarmed, with two longitudinal medial rows of minutes granules medial to the spiniferous tubercles; tibial setation: ectal (IIi) $(2>1>3)$ and accessory distal tubercle (the two last St share a common base), mesal (Iili) $(3>1>$ $4>2)$, in the right side with a bifid teratological tubercle. Tarsus ectally (IiIi) $(3>1>2>4)$ and mesally (IIi) $(2>1>3)$, ectally with a row of proximal tubercles at the base of the St forming a crenulate lamella. Claw not swollen.

Legs. Coxa I with one dorsal and one retrolateral tubercles; II with one prolateral and one retrolateral tubercles; III with retrolateral tubercle partially fused with coxa IV; IV with few lateral tubercles and one prodorsal triangular small tubercle. Trochanter I-IV dorsally unarmed; trochanter I ventrally with three tubercles (one medial and two distal), and one proximal retrolateral tubercle; trochanters II-III retrolaterally swollen and with a group of tubercles; trochanter II with a retrolateral ventral large tubercle; trochanter IV proximally enlarged with retrolateral tubercles. Femora I-IV substraight (Fig. 11e) with longitudinal rows of small granules or tubercles, femur II very elongated. Patellae I-IV unarmed. Tibia I-III unarmed, II very elongated, IV with proximal groups of retrolateral and large prolateral tubercles 
VILLARREAL O. \& GARCÍA M.A.F., Four new species of Phalangodus from Colombia

Table 6. Tarsal formula of Phalangodus gyes sp. nov. (numbers in parentheses are the number of distitarsomeres).

\begin{tabular}{|c|c|c|c|c|}
\hline & Ta I & Ta II & Ta III & Ta IV \\
\hline MNRJ 08655 & $9(3)-9(3)$ & 11(3)-? & $8-8$ & $9-9$ \\
\hline MNRJ 17907 Љ & $9(3)-9(3)$ & $16(3)-16(3)$ & $8-8$ & $8-9$ \\
\hline MNRJ 17907 ఓ & $?-9(3)$ & $16(3)-15(3)$ & $8-8$ & $8-8$ \\
\hline MNRJ 17907 Љ & $9(3)-9(3)$ & $17(3)-17(3)$ & $8-8$ & $8-?$ \\
\hline MNRJ 17907 ふ & $10(3)-10(3)$ & $13(3)-14(3)$ & $8-9$ & $8-9$ \\
\hline MNRJ 17907 స & $10(3)-10(3)$ & $14(3)-16(3)$ & $8-8$ & $8-9$ \\
\hline MNRJ 17907 Љ & $8(3)-8(3)$ & $14(3)-15(3)$ & $7-7$ & $?-8$ \\
\hline MNRJ 17907 q & $9(3)-8(3)$ & 13(3)-? & $8-8$ & $8-8$ \\
\hline MNRJ 17907 & $9(3)-?$ & 13(3)-11(3) & $8-8$ & $8-8$ \\
\hline MNRJ 17907 & $8(3)-8(3)$ & $12(3)-12(3)$ & $7-7$ & $7-7$ \\
\hline MNRJ 17907 & $8(3)-9(3)$ & $11(3)-12(3)$ & $8-7$ & $8-9$ \\
\hline MNRJ 17907 & $8(3)-8(3)$ & $12(3)-11(3)$ & $8-7$ & $8-8$ \\
\hline MNRJ 17907 q & $9(3)-10(3)$ & $12(3)-11(3)$ & $8-7$ & $8-8$ \\
\hline MNRJ 17907 q & $9(3)-9(3)$ & $15(3)-13(3)$ & $8-8$ & $9-?$ \\
\hline
\end{tabular}

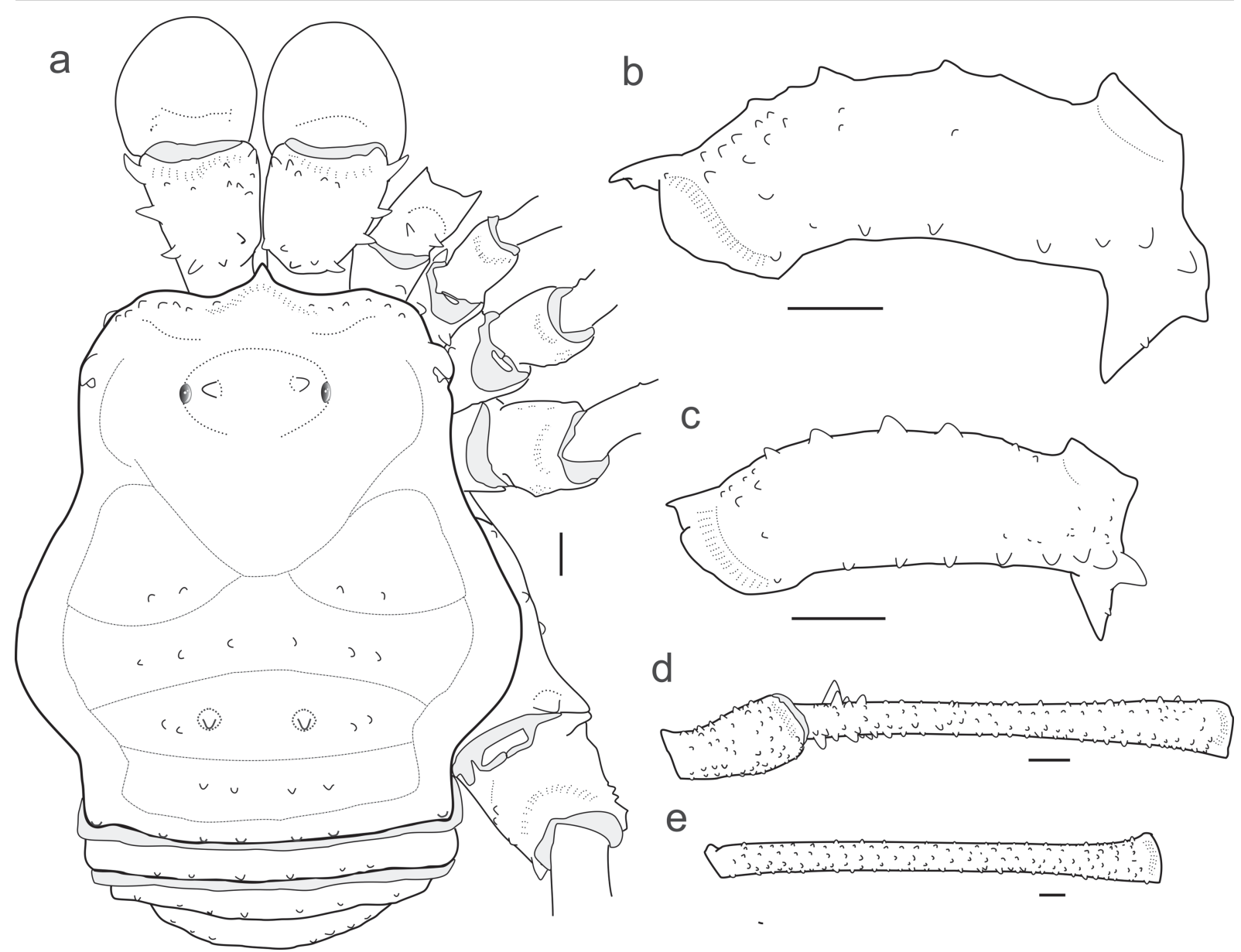

Fig. 11. Phalangodus gyes sp. nov. a-b, d-e. Holotype, $\widehat{\partial}$ (MNRJ 8655). c. Paratype, $q$ (MNRJ 17907). a. Habitus, dorsal view. b. Left pedipalp femur, ectal view. c. Left pedipalp, femur, ectal view. d-e. Right leg IV. d. Patella and tibia, dorsal view. e. Femur, dorsal view. Scale bars $=1 \mathrm{~mm}$. 
(Fig. 11d). Metatarsus II enlarged and pseudosegmentated, IV with clear ringed marks. Claws III-IV smooth. Ratio Fe IV/scutum $=1.12$. Tarsal counts in Table 6.

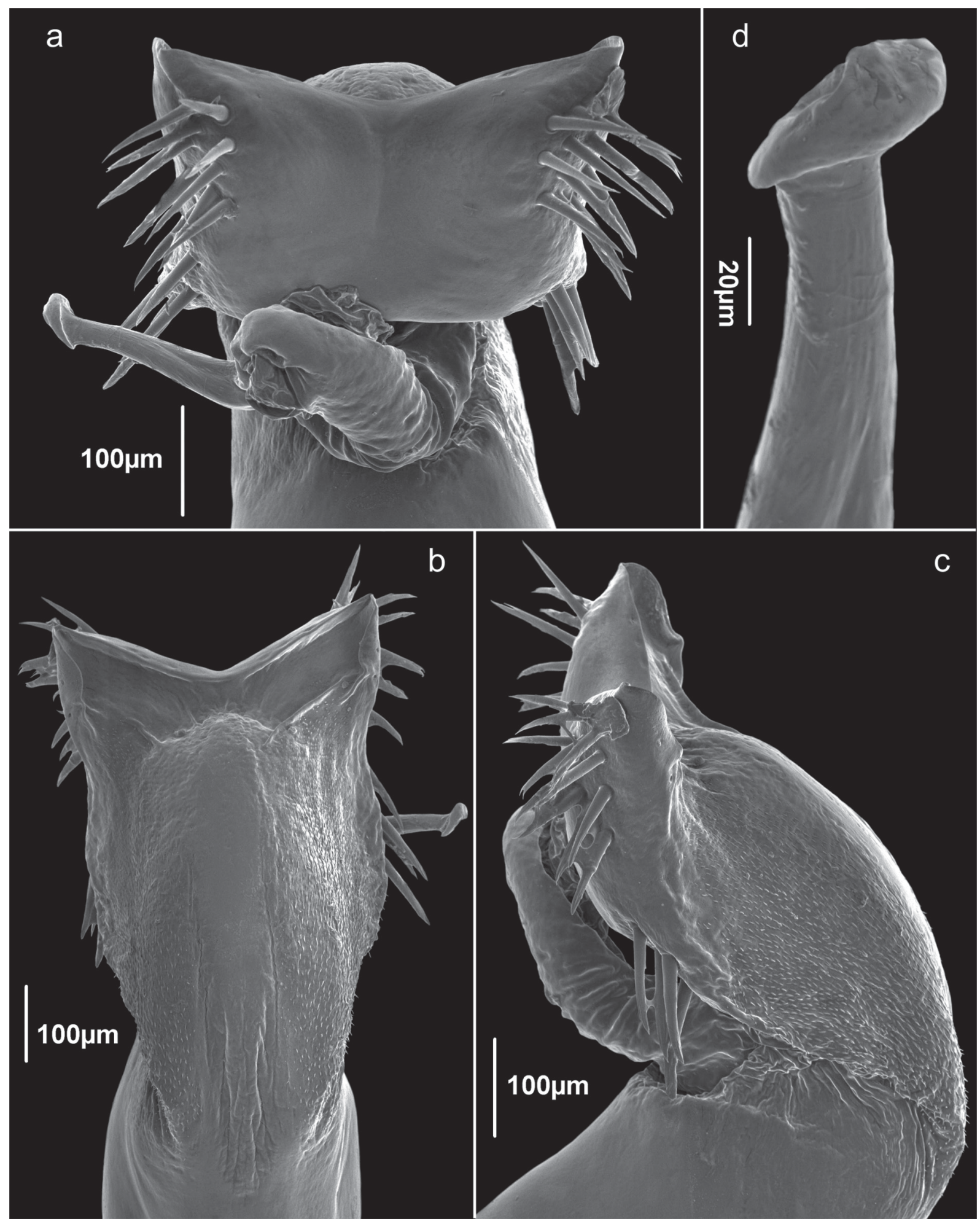

Fig. 12. Phalangodus gyes sp. nov., paratype, $\widehat{\jmath}$ (MNRJ 17907). Distal portion of the penis. a. Dorsal view. b. Ventral view. c. Lateral view. d. Stylar caps, lateral view. 
GenITALIa (Figures refer to paratype MNRJ 17907). Ventral plate subrectangular, with mid-constriction, the proximal lobes curved and laterodistal border sligthly projected, anterior border concave. Ventral surface of VP with two inverted lung-shaped fields of small, needle-like microsetae separated by a wellmarked longitudinal median elevation (Fig. 12b-c). MS forming two lateral groups: one proximal group of four pairs of large, acuminate and cylindrical setae, pointing towards to the base of the penis trunk (MS A/B); and one distal (MS C/D) group composed by 11 pairs of setae with similar shape to the distal group (Fig. 12a, c). Two pairs of very small MS E located on latero-distal flange (Fig. 12b-c). Glans sac columnar elongate, with proximal folders. Stylus straight, without processes (Fig. 12a). Stylar caps ring-shaped without lateral or ventral projections (Fig. 12d).

Coloration (in alcohol). Carapace tomato venetian red 41, reticulated in the posterior region. Abdominal scutum russet orange 51, with the lateral of scutal area I, posterior border of dorsal scutum, free tergite I and legs venetian red 41. Pedipalpal patellae - tarsi and chelicerae light vermilion, 34. Pedipalpal femora venetian red 41. Tip of cheliceral teeth, paramedian tubercles of scutal area III, and free tergites II-III red plum.

Female (MNRJ 17907)

Similar to male; differing by: carapace slightly larger; coda wider; chelicerae smaller; pedipalpal femur, patella and tibia thinner, with ventroproximal tubercles smaller; stigmatic area shorter, without the groups of granules anteriorly to stigmata; genital operculum wider; trochanters III-IV narrower; femur IV slightly thinner; tibia IV without proximal group of granules; tergite I-III with a pair of large paramedian tubercles.

Ovipositor (Fig. 7e-f). dl and vl rounded with four and two pairs of large, acuminated, single-tipped setae respectively. Dl with four pairs of ds one of them basally located; and the lateral region of the ovipositor with one group of four very long and thin dorso-lateral setae, reaching the base of ds (Fig. 7f).

\section{Distribution}

Known only from surroundings of Ibagué (Fig. 18).

Phalangodus kuryi sp. nov. urn:lsid:zoobank.org:act:F98EE1A8-FBF4-4E2B-B701-7616C6821594

Figs 13-15, 18; Tables 7-8

\section{Diagnosis}

Phalangodus kuryi sp. nov. can be distinguished from all other species of the genus by the very low ocularium and paramedian paired small tubercles of area III (Figs 13a-b, 14a-b); ventroproximal group of tubercles of pedipalpal femora not enlarged (Fig. 14c, g). Femur IV unarmed (Fig. 14d); penis ventral plate thin in lateral view (Fig. 15e); MS A-D of the penis ventral plate grouped in one distal group (Fig 15a-c, e). Penis stylus curved (Figs 15c). Heteromorphism in males (Fig. 14c, g), evident by different sizes (length and height) of pedipalpal femora.

\section{Etymology}

The species is named after the Brazilian arachnologist Adriano B. Kury, advisor and friend, who immensely contributes to the knowledge of Opiliones worldwide. 
Table 7. Phalangodus kuryi sp. nov. measurements of body and appendage, in millimeters.

\begin{tabular}{|c|c|c|c|c|c|}
\hline & \multirow{3}{*}{$\begin{array}{c}\text { Holotype } \\
\text { (ICN-AO 1436) } \\
\curvearrowright\end{array}$} & \multicolumn{4}{|c|}{$\begin{array}{c}\text { Paratypes } \\
\text { (ICN-AO 1436.1) }\end{array}$} \\
\hline & & \multicolumn{2}{|c|}{$\widehat{\delta}(\mathrm{n}=2)$} & \multicolumn{2}{|c|}{$q(\mathbf{n}=\mathbf{8})$} \\
\hline & & Min. & Max. & Min. & Max. \\
\hline DSL & 11.4 & 9.0 & 11.2 & 10.0 & 12.0 \\
\hline CL & 6.0 & 4.6 & 6.0 & 4.8 & 6.0 \\
\hline $\mathbf{C W}$ & 8.2 & 5.8 & 7.6 & 6.4 & 7.4 \\
\hline $\mathbf{A L}$ & 5.4 & 4.4 & 5.2 & 5.2 & 6.2 \\
\hline AW & 10.2 & 7.4 & 9.6 & 9.2 & 10.2 \\
\hline IOD & 3.4 & 2.2 & 2.6 & 2.2 & 2.6 \\
\hline $\mathrm{BaCh}$ & 2.6 & 1.8 & 2.0 & 1.8 & 2.4 \\
\hline FePp & 6.0 & 3.8 & 4.0 & 3.2 & 4.2 \\
\hline PaPp & 3.0 & 2.2 & 2.2 & 1.8 & 4.4 \\
\hline TiPp & 3.8 & 2.4 & 3.4 & 2.4 & 4.0 \\
\hline $\mathrm{Fe} \mathrm{I}$ & 6.8 & 5.2 & 7.0 & 4.4 & 6.2 \\
\hline Fe II & 14.8 & 10.2 & 15.2 & 9.6 & 12.6 \\
\hline Fe III & 11.2 & 7.8 & 11.2 & 8.2 & 10.6 \\
\hline Fe IV & 13.0 & 10.0 & 14.6 & 8.4 & 12.4 \\
\hline Ti I & 5.2 & 3.8 & 5.0 & 4.0 & 5.8 \\
\hline Ti II & 14.0 & 9.2 & 12.0 & 8.2 & 12.0 \\
\hline Ti III & 6.6 & 5.0 & 6.4 & 5.4 & 6.4 \\
\hline Ti IV & 9.4 & 7.4 & 8.8 & 6.6 & 9.8 \\
\hline
\end{tabular}

\section{Type material}

\section{Holotype}

COLOMBIA: đo (ICN AO 1436), Magdalena, Santa Marta, village of Minca, sector San Lorenzo, 2200 m, 30 Aug. 2014, W. Galvis and J. Moreno leg.

\section{Paratypes}

COLOMBIA: $1 \hat{\jmath}, 6$ 우 (ICN AO 1436.1), same data as holotype; $1 \hat{\jmath}, 2$ 우, 1 juvenile (FMNH AK 229), Magdalena, Sierra Nevada de Santa Marta, Inderena Station in Cerro San Lorenzo, under stones, 1700-2200 m, 9-12 Jul. 1970, B. Malkin and P. Burchard leg.

\section{Description}

Male (ICN AO 1436)

Measurements of body and appendage in Table 7.

Dorsum. Dorsal scutum type alpha (Fig. 13a). Abdominal scutum widest at scutal groove II; lateral borders of dorsal scutum smooth. Carapace mostly smooth, with a group of granules on the anterolateral region. Ocularium unarmed, very low, without median depression. Integumentary dome of ozopore raised and conspicuous. Abdominal scutum well delimited, divided into four marked areas: scutal area I divided into left and right halves by invasion of the scutal area II; scutal areas I-II each with two pair of granules; scutal area III with a paramedian pair of low tubercles (Fig. 13a-b). Posterior border of scutum 
VILLARREAL O. \& GARCÍA M.A.F., Four new species of Phalangodus from Colombia

Table 8. Tarsal formula of Phalangodus kuryi sp. nov. (numbers in parentheses are the number of distitarsomeres).

\begin{tabular}{|c|c|c|c|c|}
\hline & Ta I & Ta II & Ta III & Ta IV \\
\hline ICN AO 1436 ○ & $9(3)-9(3)$ & $12(3)-13(3)$ & $8-8$ & $9-9$ \\
\hline FMNHAK229 ઊે & $9(3)-9(3)$ & $?-14(3)$ & $8-8$ & $9-9$ \\
\hline ICN AO 1436 웅 & $10(3)-10(3)$ & $13(3)-14(3)$ & $8-8$ & $9-9$ \\
\hline ICN AO 1436 웅 & $10(3)-10(3)$ & $13(3)-13(3)$ & $8-8$ & 9-9 \\
\hline ICN AO 1436 울 & $9(3)-?$ & $12(3)-11(3)$ & $8-8$ & $9-9$ \\
\hline ICN AO 1436 웅 & $10(3)-9(3)$ & $11(3)-13(3)$ & $8-8$ & $9-9$ \\
\hline ICN AO 1436 우 & $9(3)-9(3)$ & $13(3)-13(3)$ & $8-8$ & $9-9$ \\
\hline ICN AO 1436 웅 & $9(3)-9(3)$ & 13(3)-? & $8-8$ & $9-9$ \\
\hline FMNHAK229 & $9(3)-9(3)$ & $12(3)-?$ & $8-8$ & $9-9$ \\
\hline FMNHAK229 + & $10(3)-10(3)$ & $14(3)-13(3)$ & $8-8$ & $9-9$ \\
\hline
\end{tabular}

straight and unarmed, with a row of four minute tubercles on a row (Figs 13a, 14a). Free tergites I-III with few granules.

VENTER. Stigmatic area with two pairs of paramedian granules. Stigmata large, oval and slightly oblique. Coxa I densely covered with irregular rows of tubercles; coxa II longer than coxae I and III, with three rows of small tubercles, the median ones more conspicuous; coxa III with a curved median row of granules and distal minute tubercles sparsely distributed, with the posterior border sigmoid; coxa IV
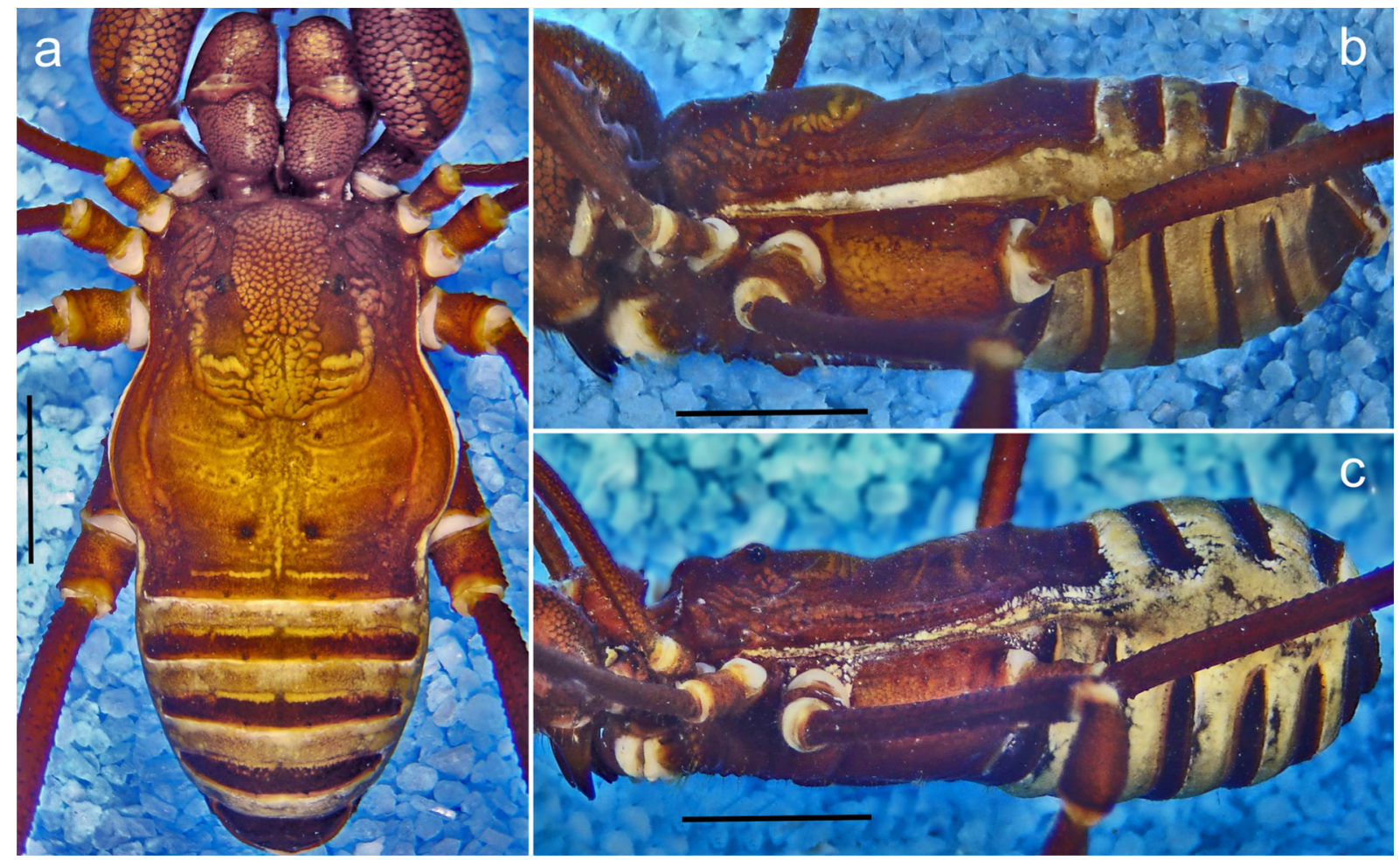

Fig. 13. Phalangodus kuryi sp. nov. a-b. Holotype, ô (ICN-AO-1436). a. Habitus, dorsal view. b. Habitus, lateral view. c. Paratype, $q$ (ICN-AO-1436.1), habitus, lateral view. Scale bars $=5 \mathrm{~mm}$. 
strongly backward, with sparsely distributed granules, the lateral larger. Free sternites each with a row of small granules.

ChELICERA (Fig. 13a). Basichelicerite very swollen, bulla with sparsely distributed dorsal tubercles. Hand slightly enlarged, its frontal region covered by tubercles of different sizes. Fixed finger with a proximal minute tooth, three median teeth decreasing in size distally and one subdistal laminar tooth. Movable finger with a proximal wide and low tooth, a small gap and three teeth (the proximal one rounded and the two distal forming a lamella).

PediPalpus (Fig. 14c). Trochanter with two tubercles on a dorsal protuberance, ventrally with two fused median tubercles and two ventrolateral tubercles. Femur strongly inflated, dorsally curved and ventrally straight in lateral view, with a dorsoproximal row of forward curved tubercles, ventrally with a proximal group of three small tubercles in a common base and two ventral rows of tubercles, ectal largest. Patella short (ratio $\mathrm{FePp} / \mathrm{PaPp}=2.0$ ), subsquare in dorsal view, smooth. Tibia inflated, dorsally smooth; tibial

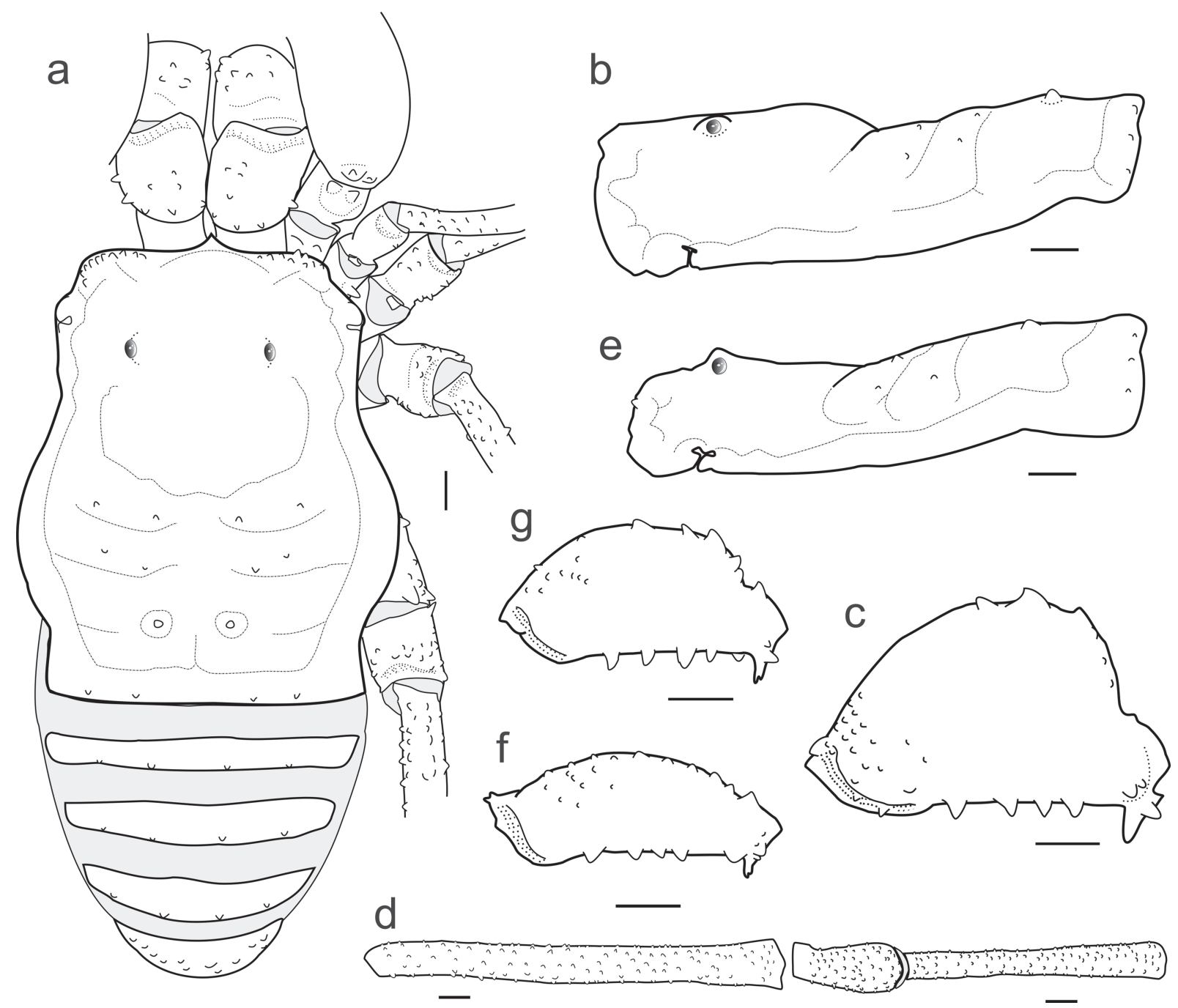

Fig. 14. Phalangodus kuryi sp. nov. a-d. Holotype, $ð$ (ICN-AO-1436). e-f. Paratype, $q$ (ICNAO-1436.1). g. Paratype, ơ (ICN-AO-1436.1). a. Habitus, dorsal view. b. Dorsal scutum, lateral view. c. Pedipalpal femur, ectal view. d. Right leg IV: femur, patela and tibia, dorsal view. e. Dorsal scutum, lateral view. f. Pedipalpal femur, ectal view. g. Pedipalpal femur, ectal view. Scale bars $=1 \mathrm{~mm}$. 
setation: ectal (iili) $(3>1>4>2)$ (the two last one St share a common base), with a row of proximal tubercles and mesal (Iili) $(3>1>4>2)$, with some ventral granules. Tarsus inflated, dorsally smooth, ectally with four distally shifted St (IiIi) $(3>1>2>4)$; mesally with three St (iii) $(1>2>3)$ (teratological condition in the right side with a group of five small St). All spines of St reduced. Claw substraight, not swollen, its length approximately the same as tarsus.

LEgs. Coxa I with one prolateral and one retrolateral tubercles; II with two prolateral, two dorsal and three retrolateral tubercles; III with one prolateral and one retrolateral tubercles; IV with few lateral tubercles and a prolateral group of conical granules. Trochanters I-IV finely granulate; trochanter I with one large mesoventral tubercle and few retrolateral tubercles; trochanter II ditto, with a group

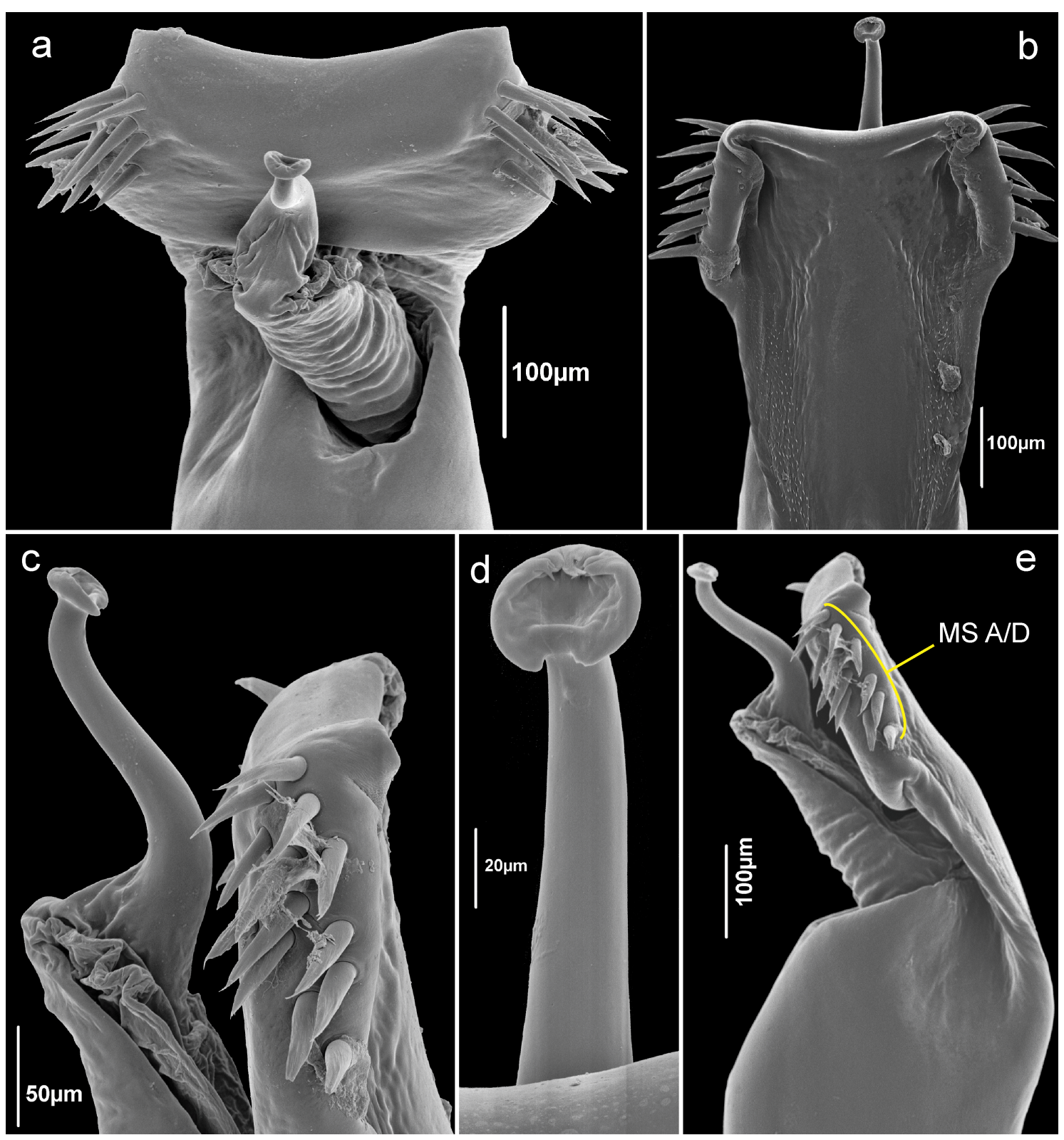

Fig. 15. Phalangodus kuryi sp. nov., holotype, ô (ICN-AO-1436). Penis, distal portion. a. Dorsodistal view. b. Ventral view. c. Detail of MS, lateral view. d. Stylar caps, ventral view. e. Lateral view. Abbreviations: $\mathrm{MS}=$ macrosetae. 
of prolateral distal tubercles; trochanter III with tubercles irregularly distributed, the retrolateral one largest; trochanter IV slightly widened at base, irregularly tuberculate. Femur I slightly curved, femora II-IV straight; femora I-IV with longitudinal rows of small granules (Fig. 14d). Patellae I-IV unarmed; the III-IV slightly swollen. Tibia I-IV unarmed, straight (Fig. 14d). Metatarsus IV without clear ringed marks on the subdistal portion. Claws III-IV smooth. Ratio Fe IV/scutum $=1.14$. Tarsal counts in Table 8 .

Genitalia. Ventral plate sub trapezoidal with subdistal constriction and distal parabolic concavity., Ventral surface of VP with two elongated fields of small and needle-like microsetae with a longitudinal medial well marked elevation (Fig. 15a-b). MS forming a single group distally positioned (A/D), composed by 12-13 pairs of acuminate and cylindrical setae (Fig. 15a-c, e). Two pairs of very small MS E close together in the distal region of the flange (Fig. 15b). Glans sac columnar elongate, with numerous proximal folders (Fig. 15a, e) Stylus curved, without processes (Fig. 15c). Stylar caps ringshaped without lateral or ventral projections (Fig. 15d).

Coloration (in alcohol). Carapace with two paramedian areas of homogenous color paprika 38, three longitudinal stripes and posterior area reticulated squash yellow 83. Abdominal scutal areas reticulated between squash yellow 83 and pastel yellow 84. Paramedian tubercles of scutal area III, free tergites, anal operculum and coxae I-IV venetian red 41. Chelicerae and pedipalps reticulated dark wine 44 on light amber 71 .

Female (ICN AO 1436.1)

Similar to males, differing by: carapace shorter and lower, with ocularium and spines higher in lateral view (Fig. 14b, e); coda wider and longer; chelicerae smaller; pedipalpal femur, patella and tibia thinner; femur IV curved and slightly thinner. Sexual dimorphism evident in alpha males with pedipalpal femora much thicker than female (Fig. 14c, f-g).

Ovipositor. $\mathrm{dl}$ and $\mathrm{vl}$ rounded with three and two large, acuminated, single-tippedsetae respectively. Dl with three pairs of ds without the basal located pair. and the lateral region of the ovipositor with a pair of short dorso-lateral setae.

\section{Distribution}

Known only from surroundings of Minca, Sierra Nevada de Santa Marta (Fig. 18).

Phalangodus palpiconus (Roewer, 1943)

Temucus palpiconus Roewer 1943: 27, pl. 3, fig. 20 (see the complete citations in Kury 2003: 96).

Temucus palpiconus - Hara et al. 2014: 569.

\section{Diagnosis}

Lateral border of DS and scutal areas I and IV densely granulate (see, e.g., Hara et al. 2014: figs 2-3); ocularium high, rounded; femur IV straight; Scutal area III with a pair of paramedian acuminate high subparallel tubercles (shared with $P$. cottus sp. nov.); pedipalpal claw of the males swollen (shared with $P$. anacosmetus and $P$. briareos sp. nov.); MS of the VP without obvious gap (slightly similar to $P$. kuryi sp. nov.).

\section{Type material}

CHILE: 1 ô, holotype (SMF), Temuco RII 13181/74. 


\section{Discussion}

\section{Sexual dimorphism in Phalangodus}

Sexual dimorphism is frequent in Gonyleptoidea, and the differences between the sexes are evident in numerous structures, mainly in males. The main characters that present striking differences are: chelicera hand swollen or armed with spines, tarsomeres inflated, presence of modified setae on the metatarsus, tibiae and femora of legs III and IV armed and swollen, stigmatic area elongated or armed posteriorly with processes or tubercles; carapace expanded posteriorly, scutal areas elevated (in females) or armed with bizarre tubercles (in males), anal operculum with differentiated tubercles and coloration pattern with additional spots on the females. More detailed information is summarized in table 9.

Within the Cranaidae, interesting cases of sexual and intra-sexual dimorphism can be found, with alpha and beta males recognized (see, e.g., Orrico \& Kury 2009; Villarreal et al. 2015). The pedipalps of cranaids particularly, undergoes extreme modification in some genera, acquiring an astonishing elongation in many Stygnicranainae, where some males have pedipalps longer than females or larger than females and other males (beta males), e.g., Tryferos Roewer, 1931 and Stygnicranaus (Orrico \& Kury 2009, 2009).

As explained by Villarreal et al. (2015), an intermediary degree of this elongation can be observed in some species of Ventrifurca Roewer, 1913, where only sexual dimorphism is known. Differences in size and stockiness of the femur between both sexes occur at least in Panalus Goodnight \& Goodnight, 1947 and Spirunius Roewer, 1932 where males are larger and a dorsal crest is observed in males of Chiriboga Roewer, 1959 and Carsevennia Roewer, 1913 (unpublished data).

In Phalangodus both kinds of dimorphism occur, sexual and intrasexual. Sexually dimorphic pedipalps are present in all known species of the genus (e.g., Figs 9b-c, 11b-c, 14c, f-g) and dimorphic in "alpha" and "beta" males pedipalps are present at least in P. kuryi sp. nov. (Fig. 14c, g). Differences in length and height of the carapace between males and females are also present in some species of the genus. $P$. anacosmetus and some other species have males with ocularium-carapace ratio (h1/h3) higher than females (Fig. 1b, d). The male carapace of $P$. kuryi sp. nov.) is extended posteriorly, invading the scutal area I (Figs 13a, 14a). This expansion of the carapace however, is not exclusive to Phalangodus, being also present homoplasically in Chiriboga as noticed by Orrico \& Kury (2009) char. 7(0), Kury \& Villarreal (2015) char. 3(1) and Pinto-da-Rocha \& Bonaldo (2011) char. 10(1). Three species of Phalangodus (P. anacosmetus, $P$. briareos sp. nov. and P. palpiconus) have sexual dimorphic claws in the pedipalps, being strongly swollen and dark at the base on the males.

Some dimorphic characters like pedipalpal tarsal claw and extremely swollen femora on alpha males, seem to be restricted to a subgroup of Phalangodus, while other cases of probably homoplasic dimorphism appear in other genera in the family, like sexual differences in coloration (Stygnicranaus), presences of ventral apophysis on the coxae IV (Phareicranaus, Stygnicranaus), elongation of pedipalps (Stygnicranainae) and size of the carapace (Chiriboga). Interestingly, many kind of sexual dimorphism are found in Stygnicranainae species.

\section{About the ovipositor morphology}

Genital morphology of the females is poorly known in Gonyleptoidea. It has been neglected and rarely used as source of taxonomic characters. Although some authors illustrated the ovipositor of some species (e.g., Goodnight \& Goodnight 1977; Šilhavý 1979; Kury 1990), only a few researchers have studied and used these characters (e.g., Martens et al. 1981; Bennett \& Townsend 2013; Walker \& Townsend 2014; Townsend et al. 2015; Brooks et al. 2015). Of the aforementioned, only Townsend et al. (2015) 
Table 9. Some examples of sexual dimorphism in Gonyleptoidea.

\begin{tabular}{|c|c|c|c|c|}
\hline Structure & Dimorphism & Suprageneric taxa & Genus/species & Source \\
\hline \multirow[t]{3}{*}{ Cheliceral hand } & \multirow[t]{3}{*}{ Swollen or armed with spines } & Agoristenidae & Avima anitas Porto \& Colmenares, 2014 & Porto \& Colmenares 2014 \\
\hline & & Cranaidae & Stygnicranaus Roewer, 1913 & Orrico \& Kury 2009 \\
\hline & & Cranaidae & Phareicranaus Roewer, 1913 & Townsend et al. 2010 \\
\hline \multirow[t]{5}{*}{ Tarsomeres } & \multirow[t]{5}{*}{ Inflated } & Cosmetidae & Many genera and species & Townsend et al. 2010 \\
\hline & & Manaosbiidae & Rhopalocranaus columbianus (Roewer, 1963) & Villarreal et al. 2015 \\
\hline & & Manaosbiidae & Saramacia Roewer, 1913 & Kury 1997 \\
\hline & & Manaosbiidae & Syncranaus Roewer, 1913 & Kury 1997 \\
\hline & & Manaosbiidae & Barrona felgenhaueri Townsend \& Milne, 2011 & Townsend \& Milne 2011 \\
\hline \multirow[t]{2}{*}{ Metatarsus carinate setae } & \multirow[t]{2}{*}{ presence (males) } & Nomoclastidae & Zygopachylus albomarginis Chamberlin, 1925 & Villarreal et al. (in press) \\
\hline & & Nomoclastidae & Quindina bella Roewer, 1914 & Villarreal et al. (in press) \\
\hline \multirow[t]{5}{*}{ Tibia/Femora III-IV } & \multirow[t]{5}{*}{ Armed or swollen } & Cosmetidae & Many genera and species & Townsend et al. 2010 \\
\hline & & Cranaidae & Phalangodus Gervais, 1842 & Hara et al. 2014 \\
\hline & & Gonyleptidae & Many genera and species & Buzatto \& Machado 2014 \\
\hline & & Stygnidae & Ricstygnus quineti Kury, 2009 & Kury 2009 \\
\hline & & Stygnidae & Many genera and species & Pinto-da-Rocha 1997 \\
\hline Pedipalps & elongated (males) & Cranaidae & Tryferos elegans Roewer, 1931 & Orrico \& Kury 2009 \\
\hline Stigmatic area & $\begin{array}{l}\text { Elongated or armed posteriorly } \\
\text { with processes (males) }\end{array}$ & Cranaidae & Ventrifurca Roewer, 1913 & Villarreal et al. 2015 \\
\hline \multirow[t]{2}{*}{ Carapace } & \multirow[t]{2}{*}{ Expanded posteriorly } & Nomoclastidae & Nomoclastes quasimodo Pinto-da-Rocha 1997 & Pinto-da-Rocha 1997 \\
\hline & & Nomoclastidae & Zamora granulata Roewer, 1928 & Kury $2012 b$ \\
\hline \multirow[t]{2}{*}{ Scutal areas } & Elevated (females) & Cranaidae & Ventrifurca & Villarreal et al. 2015 \\
\hline & Armed with bizarre tubercles (males) & Cosmetidae & Roquettea Mello-Leitão, 1931 & Ferreira \& Kury 2010 \\
\hline Anal operculum & With differentiated tubercles & Cosmetidae & Taito Kury \& Barros, 2014 & Kury \& Barros 2014 \\
\hline Coloration pattern & With additional spots (females) & Cranaidae & Phareicranaus albilineatus (Roewer, 1932) & $\begin{array}{l}\text { Villarreal \& Rodríguez } \\
2011\end{array}$ \\
\hline
\end{tabular}


and Brooks et al. (2015) have proposed and used names for the external structures associated to the ovipositor (lobes, setae, pores, etc.).

Nonetheless, we found issues regarding the structures proposed so far. Martens et al. (1981) referred to the presence of four external lobes with groups of peripheral sensory setae on the tip of the ovipositor of Laniatores. The first ones to assign names for these lobes were Townsend et al. (2015), who used "anterior lobes" and "posterior lobes" (fig. 1B) and "anterior row" and "posterior row" to name the setae associated to them (fig. 1A). In the present article, after a topological analysis we propose alternative names, on the basis of topology of these structures on the ovipositor and its relative position to the body.

Following the widely used topology for the male genitalia structures, such as the ventral process, dorsal process and the ventral plate (Martens 1986; Kury 1994; Townsend et al. 2010; Kury \& Villarreal 2015), the "anterior lobes" would be located on the dorsal face and the "posterior lobes" on the ventral face of the ovipositor. Therefore, we propose that the dorsal lobes (dl) and the ventral lobes (vl) be called "anterior lobes" and "posterior lobes" and consequently, dorsal rows (dr) and ventral rows (vr) instead of "anterior" and "posterior rows" (Fig. 7a-h). The peripheral setae (ds and vs) of all studied species are similar to those of $P$. calcariferus, with striated surface and straight and undivided tip.

The only cranaids for which SEM pictures of the ovipositor have been published is Phareicranaus calcariferus (Simon, 1879) (Bennett \& Townsend 2013: fig. 2A-F). Those images show at least one pair of accessory setae not assignable to any of the dorsal or ventral rows, positioned dorsolaterally and located slightly proximal on the ovipositor. That pair is named here as dorso-lateral setae (dls) (Fig. $7 \mathrm{a}-\mathrm{f}$ ). From six species of cranaids studied in the present article, the Dls group was found in all new species of Phalangodus here described, but was absent in Homocranaus sp. and Phareicranaus hermosa Pinto-da-Rocha \& Kury, 2003 (Fig. 7g-h). Additionally, in all the studied species of Phalangodus, but not in P. kuryi sp. nov., an increase of the quantity of Dls occurs, (Fig. $7 \mathrm{~b}, \mathrm{~d}, \mathrm{f}$ ) and could be a condition associated to some species of the genus.

On the other hand, these setae are absent in other studied families in Gonyleptoidea (e.g., Cosmetidae, Gonyleptidae, Manaosbiidae, Nomoclastidae Roewer, 1943; Kury 1990; Bennett \& Townsend 2013; Walker \& Townsend 2014; Townsend et al. 2015; Brooks et al. 2015). The taxonomic usefulness of this character should be corroborated with future studies.

\section{Stylar caps in Cranaidae}

Although the genital morphology of many species and genera of Cranaidae is still unknown, some characters from the cranaid penis have been proposed and increasingly used (e.g., stylar caps, shape of distal portion of the stylus, proximal folds of the glans, shape and number of MS C; Pinto-da-Rocha \& Bonaldo 2011; Kury 2012a; Hara et al. 2014; Kury \& Villarreal 2015; Villarreal et al. 2015). Orrico \& Kury (2009) referred to the presence of a laminar structure on the tips of the stylus in Stygnicranaus for the first time, naming it "capellum" and the "lateral paired beaks of the stylus" associated to the capellum (characters 34 and 35). Pinto-da-Rocha \& Kury (2003) and Pinto-da-Rocha \& Bonaldo (2011) called this structure "stylar subdistal pointed apophysis" (character 16 and 19, respectively). Kury (2012a) described these structures in detail, renaming it as "Stylar caps". He also indicated their presence in many cranaids, including Phalangodus anacosmetus. In the particular case of $P$. anacosmetus, Kury (2012a) classified its Stylar cap as "elongate-erythrocyte cap". Hara et al. (2014) and Kury \& Villarreal (2015) interpreted the stylar caps as absent in Phalangodus, due to its unique shape. However, as the SEM images of Phalangodus show, these are present as an elongate-erythrocyte cap, corroborating Kury's previous description (Kury 2012a). 

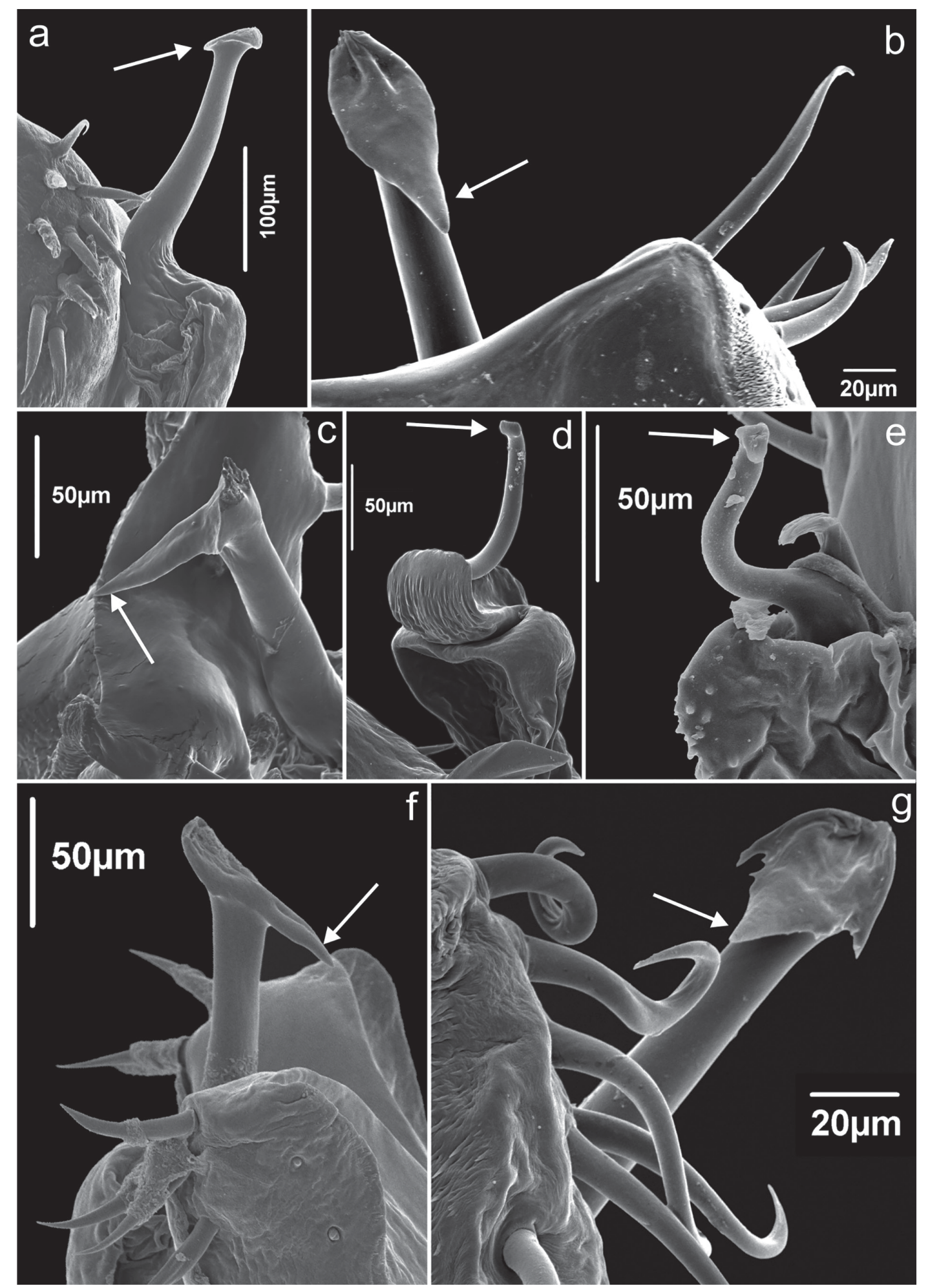

Fig. 16. Stylar caps in some cranaids species. - a-e. Cranainae. a. Phalangodus anacosmetus Gervais, 1842 (ICN-AO 1000). b. Phareicranaus giganteus Mello-Leitão, 1940 (MNRJ 19263). c. Ventrifurca caffeinica Villarreal, Kury \& Pinto-da-Rocha, 2015 (MNRJ 7038). d. Phareicranaus albilineatus author+year (MNRJ 7916). e. Phareicranaus duranti (González-Sponga, 1989) (MNRJ 7818). f. Heterocranainae. Heterocranaus sp. (MNRJ 7634). - g. Stygnicranainae. Agathocranaus sp. (MNRJ 8437). a, c, f. Lateral view. b, g. Ventral view. d-e. Oblique view. Arrows indicate stylar caps. 
The shape and size of the Stylar caps are highly variable among the Cranaidae genera and at least three main types can be recognized:

1) elongate-erythrocyte SC; this is found in Phalangodus (Figs 15c-d, 16a), two species of Stygnicranaus (Stygnicranaus alessandroi Orrico \& Kury, 2009 and S. poncedeleoni Orrico \& Kury, 2009) and Tryferos elegans Roewer, 1931, as referred by Kury (2012a). This author proposed a similarity between the SC of these species and those found in Phareicranaus gracilis (Pinto-da-Rocha \& Kury, 2003), P. singularis (H. Soares, 1970) and Zannicranaus morlacus Kury, 2012. Nonetheless, we consider the SC of these three species more similar to the kind described for other Amazonian Phareicranaus (e.g., P. divisor Pinto-da-Rocha \& Bonaldo, 2011; P. onorei Pinto-da-Rocha \& Kury, 2003; P. rohei Colmenares \& Tourinho, 2014) and the Andean species Zannicranaus monoclonius Kury, 2012.

2) small, laminar and sub-square stylar cap; this is present in some species of Phareicranaus (Fig. 16d-e).

3) blade-shaped stylar cap; this can be found in many genera of Cranainae (e.g., Phareicranaus in part, Ventrifurca) (Fig. 16b-c), Heterocranainae (Heterocranaus) (Fig. 16f) and Stygnicranainae (Agathocranaus) (Fig. 16g).

Additionally, a particular structure associated to the tip of stylus is known in Prostygnus Roewer, 1913 (Fig. 17a), which is more similar to those found in Cosmetidae (Fig. 17b), as mentioned in Kury (2012a). Possibly this is not homologous to the stylar caps of other cranaids.
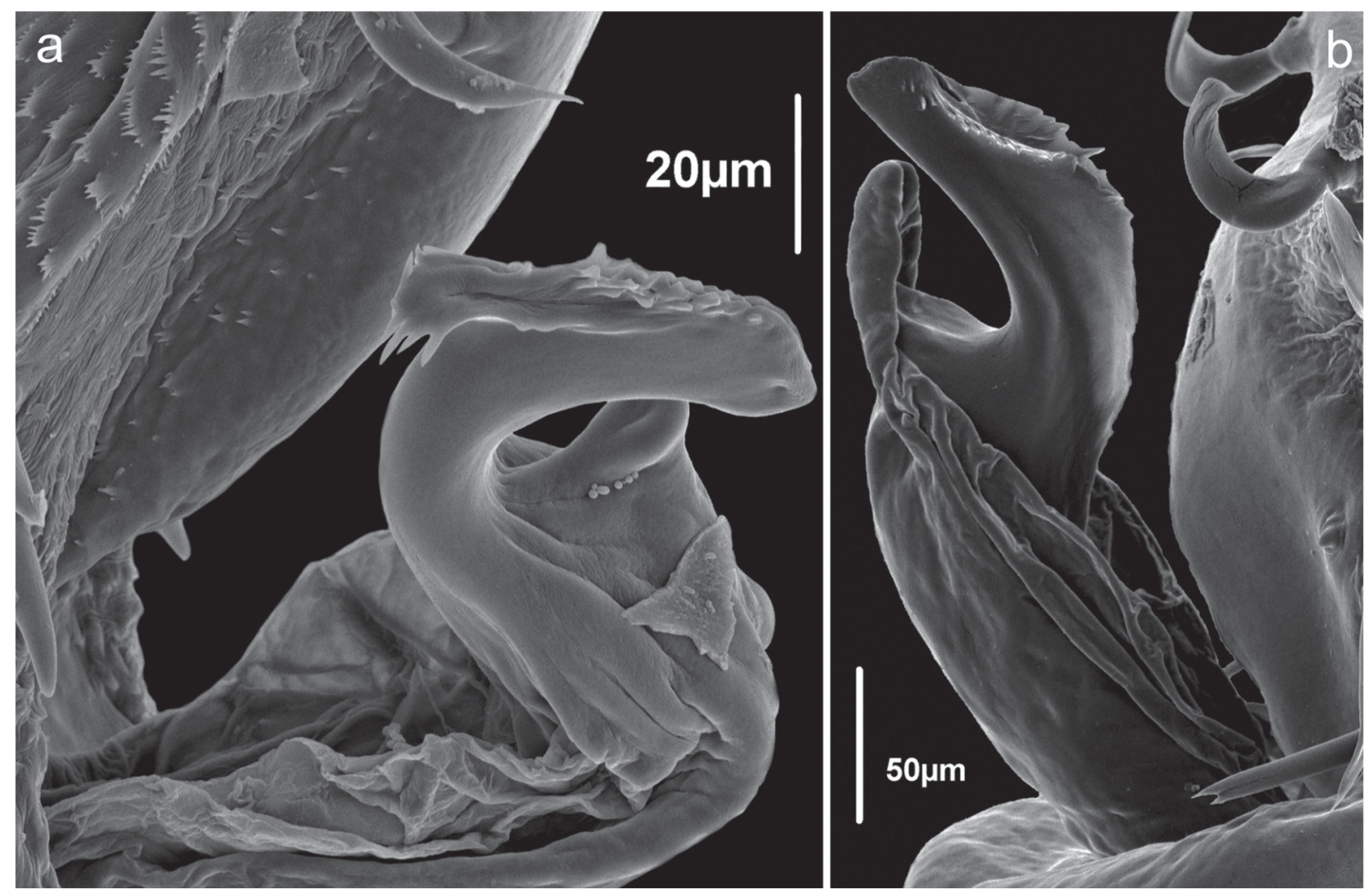

Fig. 17. Penis glans and stylus, lateral view. a. Prostygnus sp., Cranaidae: Prostygninae (MZUSP 57274). b. Flirtea quinquilineata (Simon, 1879), Cosmetidae: Cosmetinae (ICN-AO 465). 


\section{Remarks about geographical records of $P$. anacosmetus}

According to Kury $(1996,2003)$, P. anacosmetus is recorded from three Colombian localities, two of them associated to P. anacosmetus (Cundinamarca and Boyacá) and the third linked to the type locality of Allocranaus giganteus (North of Santander), a species currently under synonymy with P. anacosmetus (see remarks on the species complementary description).

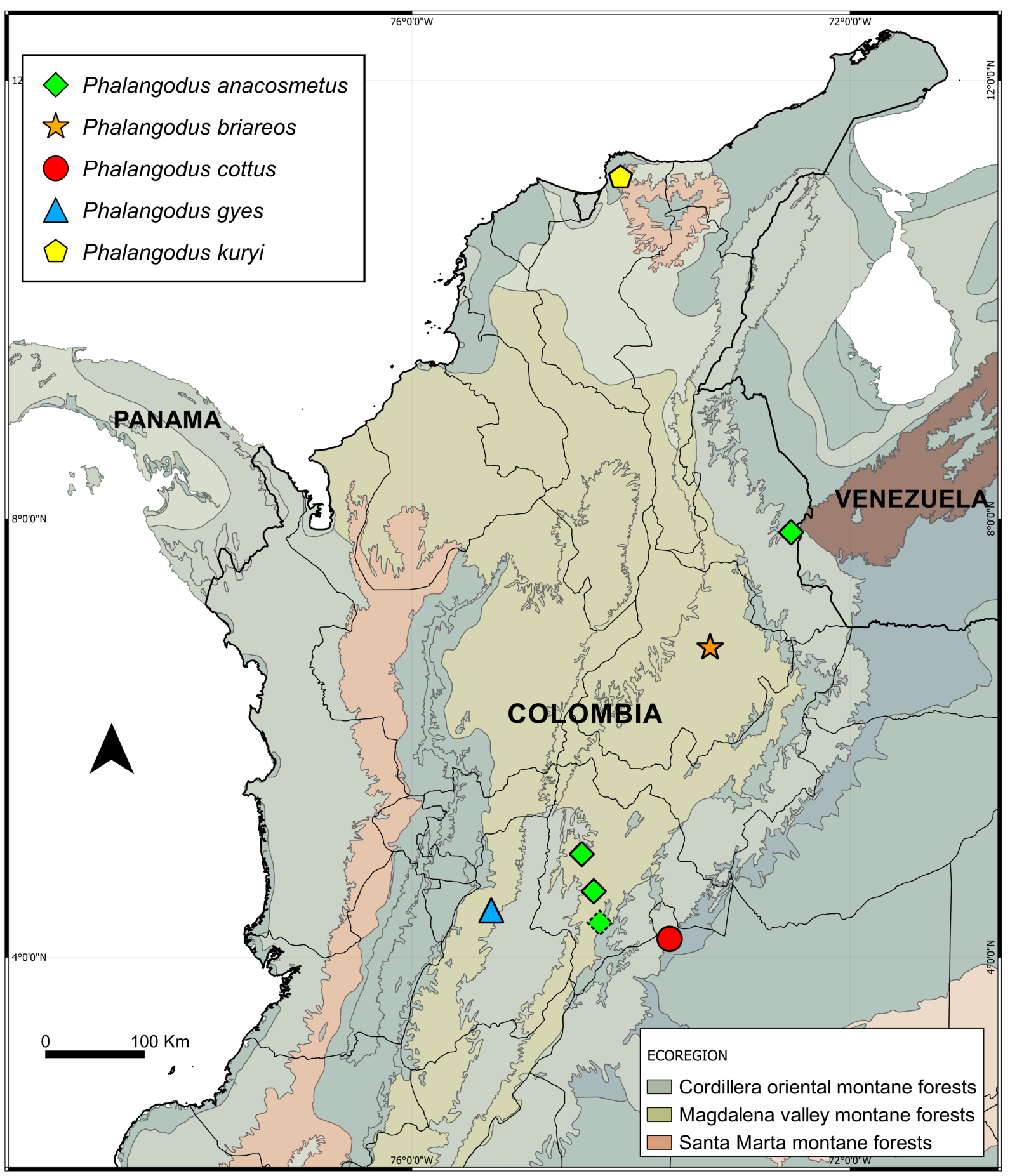

Fig. 18. Map of geographical records of Phalangodus spp. in Colombia (diamond with interrupted line corresponds to Boca del Monte record). 
Gervais (1842) recorded Phalangodus anacosmetus from New-Holland (nowadays Australia). Simon (1879), as explained by Kury (1996), noticed that the locality provided by Gervais (1842) was erroneous, and proposed Colombia as the correct provenance. Afterwards, Roewer (1913) recorded this species from Boca del Monte, Colombia, without further geographical details. Kury (1996) interpreted that Roewer's locality (Boca del Monte) could correspond to Boyacá department.

Considering that (1) Roewer (1912) described two cosmetids from a locality cited as "between Tambo and Boca del Monte, Tequendama, Columbien, 2400-2600 m" (the detailed location can be found in Gómez (2011)) one year before publishing the record of P. anacosmetus; (2) There are two records of Phalangodus anacosmetus from Sasaima (Kury 1996), and some new records from San Antonio del Tequendama and La Mesa; and (3) Sasaima, San Antonio and La Mesa are located in Cundinamarca, $30-40 \mathrm{~km}$ at North of a ville called Boca del Monte, in Pasca (Fig. 18); we infer that this last locality is the place referred to by Roewer (1912) instead of Boyacá, as stated by Kury (1996).

\section{Acknowledgements}

We are indebted to C. Griswold and D. Ubick (CAS), P. Sierwald (FMNH), E. Flórez and W. Galvis (ICN), A. Pérez-García (Museo Argentino de Ciencias Naturales), A. Santos (UFMG, Universidade Federal de Minas Gerais) and S. García (Universidade de São Paulo) for the loan and/or donation of material. To A.B. Kury (MNRJ) for providing facilities for this study, for kindly donate the figure 6 and for his constant comments on systematics and taxonomy of harvestmen. Thanks to P. Castanheira (UFRJ) and G. Silva de Miranda (University of Copenhagen) for language revision of an early version of the ms. M. Medrano (MNRJ) made suggestions on the figures. J. Uribe and S. Galvis kindly donated photographs of living specimens. To two anonymous referees for providing invaluable comments. The SEM micrographs were taken in the SEM lab of Marine Diversity of the MNRJ (financed by PETROBRAS) with the kind assistance of C. Messias. The postgraduate program in Zoology (PPGZoo$\mathrm{MN} / \mathrm{UFRJ}$ ) supported the financial costs of SEM pictures. This study is co-funded by $\mathrm{PhD}$ grant CAPES (PEC-PG 5900115) to OVM and MsC grant CNPq (\#190585/2013-7) to AFG.
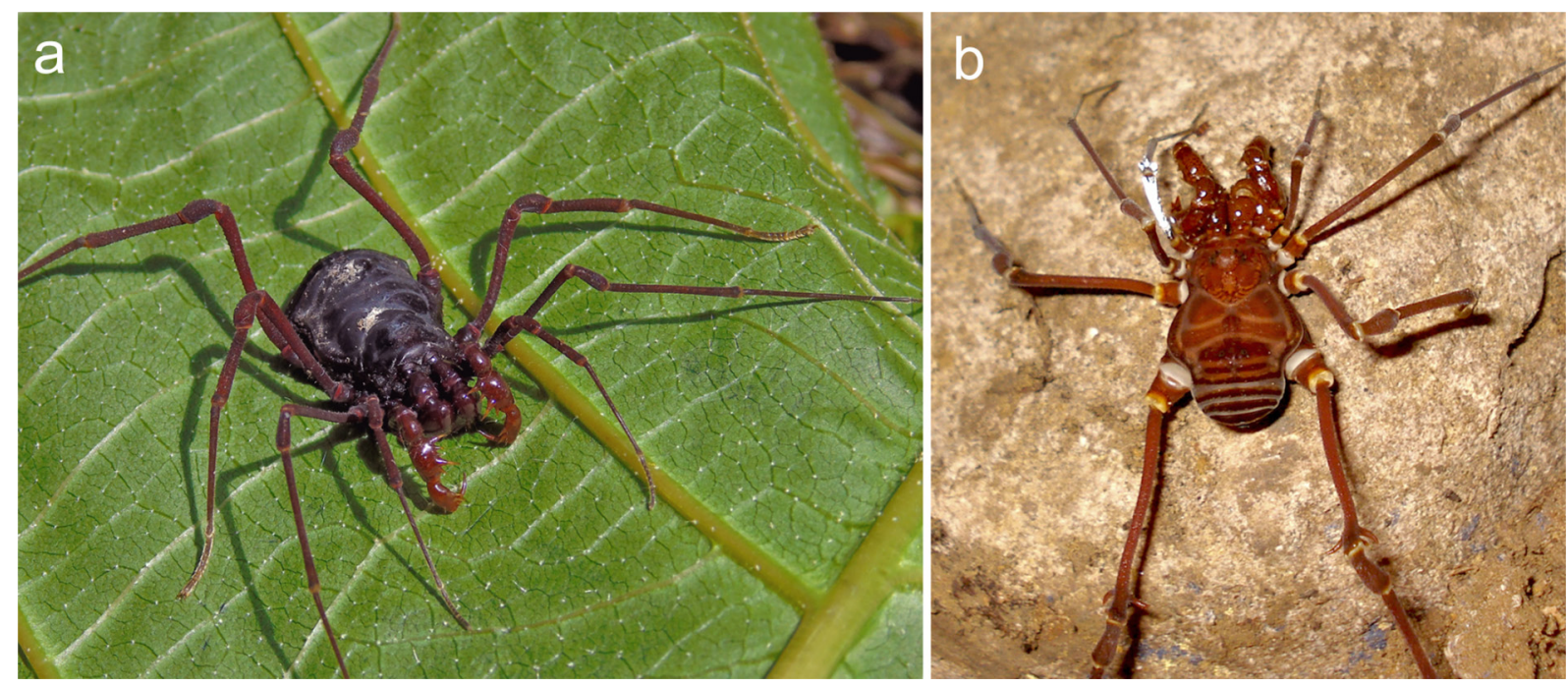

Fig. 19. Photographs of living specimens. a. Phalangodus anacosmetus Gervais, 1842 , $q$. b. Phalangodus

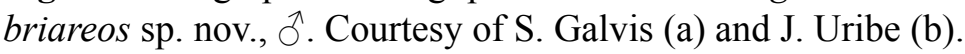




\section{References}

Agassiz L. 1846. Nomenclatoris zoologici Index Universalis, continens Nomina systematica Classium, Ordinum Familiarum et Generum Animalium omnium, tam viventium quam fossilium, secundum ordinem alphabeticum unicum disposita, adjectis homonymiis plantarum, nec non varis adnotationibus et emendationibus. Soloduri, Sumtibus Jent et Gassmann.

Bennett M.K. \& Townsend V.R. 2013. Reproductive morphology of three species of Neotropical harvestmen (Opiliones, Laniatores, Gonyleptoidea). Journal of Morphology 274: 1415-1424. http:// dx.doi.org/10.1002/jmor.20191

Brooks E.A., Townsend V.R., Allen E.A. \& Tuthill M.A. 2015. Interspecific variation in ovipositormorphology among Manaosbiid and Nomoclastid Harvestmen (Arachnida, Opiliones, Laniatores). Acta Zoologica 00: 1-10. http://dx.doi.org/10.1111/azo.12150

Buzatto B.A. \& Machado G. 2014. Male dimorphism and alternative reproductive tactics in harvestmen (Arachnida: Opiliones). Behavorial Processes 109 (Part A): 2-13. http://dx.doi.org/10.1016/j. beproc. 2014.06 .008

Canals J. 1939. Nuevos opiliones de la Argentina. Notas Museo de La Plata, Zoología 4 (18): 143-156.

Da Silva M.B. \& Gnaspini P. 2009. A systematic revision of Goniosomatinae (Arachnida: Opiliones: Gonyleptidae), with a cladistic analysis and biogeographical notes. Invertebrate Systematics 23: 530624. http://dx.doi.org/10.1071/IS09022

Erichson G.F. 1845. Nomina systematica generum arachnidarum, tam viventium quam fossilium, secundum ordinem alphabeticum disposita, adjectis auctoribus, libris in quibus reperiuntur, anno editionis etymologia et familiis ad quas pertinent. In: Agassiz L. (ed.) Nomenclator zoologicus, continens nomina systematica generum animalium tam viventium quam fossilium, secundum ordinem alphabeticum disposita, adjectis auctoribus, libris, in quibus reperiuntur, anno editionis etymologia et familiis, ad quas pertinent, in singulis classibus: $\mathrm{i}-\mathrm{iv}, 1-14$. Sumtibus et Typis Jent et Gassmann, Soloduri.

Ferreira C.P. \& Kury A.B. 2010. A review of Roquettea, with description of three new Brazilian species and notes on Gryne (Opiliones, Cosmetidae, Discosomaticinae). Zoological Science 27: 697-708. http:// dx.doi.org/10.2108/zsj.27.697

Gervais P. 1842. Description et figures de quatre espèces nouvelles de Phalangiens. Magasin de zoologie, d'anatomie comparée et de palaeontologie de Paris (Arachnides) (Série 2) 4: 1-5.

Gómez G.A. 2011. La Expedición Helvética: viaje de exploración cientifica en Colombia en 1910 de los profesores Otto Fuhrmann y Eugène Mayor. Bogotá, Editorial Pontificia Universidad Javeriana, Colciencias, Embajada de Suiza.

Goodnight C.J. \& Goodnight M.L. 1977. Laniatores (Opiliones) of the Yucatán Peninsula and Belize (British Honduras). Bulletin of the Association for Mexican Cave Studies 6: 139-166.

Hara M.R., Pinto-da-Rocha R. \& Villarreal M.O. 2014. Revision of the cranaid genera Phalangodus, Iquitosa and Aguaytiella (Opiliones: Laniatores: Gonyleptoidea). Zootaxa 3814 (4): 567-580. http:// dx.doi.org/10.11646/zootaxa.3814.4.8

Kury A.B. 1990. [Notes on Mitobatinae I]. Synonymic notes on Mitobates Sundevall, with redescription of the type species, M. conspersus (Perty) (Opiliones, Gonyleptidae, Mitobatinae). Bulletin of the British Arachnological Society 8 (6): 194-200.

Kury A.B. 1994. Early lineages of Gonyleptidae (Arachnida Opiliones Laniatores). Tropical Zoology 7 : 343-353. 
Kury A.B. 1996. A review of Phalangodus Gervais (Opiliones, Cranaidae). Bulletin of the British Arachnological Society 10 (5): 178-180.

Kury A.B. 1997. The genera Saramacia Roewer and Syncranaus Roewer, with notes on the status of the Manaosbiidae (Opiliones, Laniatores). Boletim do Museu Nacional, Nova Série Zoologia, Rio de Janeiro 374: 1-22.

Kury A.B. 2003. Annotated catalogue of the Laniatores of the New World (Arachnida, Opiliones). Revista Ibérica de Aracnología, vol. especial monográfico 1, Grupo Ibérico de Aracnología - Sociedad Entomológica Aragonesa, Zaragoza.

Kury A.B. 2009. A new genus of Stygninae from a relictual rainforest in Ceará, northeastern Brazil (Opiliones, Laniatores, Stygnidae). Zootaxa 2057: 63-68.

Kury A.B. 2012a. A new genus of Cranaidae from Ecuador (Opiliones: Laniatores). Zootaxa 3314: $31-44$.

Kury A.B. 2012b. First report of the male of Zamora granulata Roewer 1928, with implications on the higher taxonomy of the Zamorinae (Opiliones, Laniatores, Cranaidae). Zootaxa 3546: 29-42.

Kury A.B. 2013. Order Opiliones Sundevall, 1833. In: Zhang Z.-Q. (ed.) Animal Biodiversity: An Outline of Higher-level Classification and Survey of Taxonomic Richness (Addenda 2013). Zootaxa 3703 (1): 27-33. http://dx.doi.org/10.11646/zootaxa.3703.1.7

Kury A.B. \& Barros C.M. 2014. A new genus and eight new species of Amazonian cosmetines (Opiliones, Laniatores, Cosmetidae). Zoological Studies 53: 1-46.

Kury A.B. \& Medrano M. 2016. Review of terminology for the outline of dorsal scutum in Laniatores (Arachnida, Opiliones). Zootaxa 4097 (1): 130-134. http://dx.doi.org/10.11646/zootaxa.4097.1.9

Kury A.B., Villarreal M.O. \& Costa C.S. 2007. Redescription of the type species of Cynorta Koch, 1839 (Arachnida, Opiliones, Cosmetidae). Journal of Arachnology 35 (2): 325-333.

Kury A.B. \& Villarreal M.O. 2015. The prickly blade mapped: establishing homologies and a chaetotaxy for macrosetae of penis ventral plate in Gonyleptoidea (Arachnida, Opiliones, Laniatores). Zoological Journal of Linnean Society 174: 1-46. http://dx.doi.org/10.1111/zoj.12225

Martens J., Hoheisel U. \& Götze M. 1981. Vergleichende Anatomie der Legeröhren der Opiliones als Beitrag zur Phylogenie der Ordnung (Arachnida). Zoologische Jahrbücher, (Abteilung für Anatomie und Ontogenie der Tiere) 105 (1): 13-76.

Martens J. 1986. Die Großgliederung der Opiliones und die Evolution der Ordnung (Arachnida). In: Barrientos J.A. (ed.) Actas del X Congreso Internacional de Aracnologia (Jaca, Spain, September 1986) 1: 289-310. Barcelona, Juvenil.

Mello-Leitão C.F. de 1939. Dois gêneros e sete espécies de Gonyleptidas sulamericanos. Boletim Biológico (Nueva Série) 4 (3): 345-351.

Mello-Leitão C.F. de 1940. Un solifugo da Argentina e alguns opiliões da Colômbia. Annaes da Academia Brasileira de Sciencias 12 (4): 301-311.

OlsonD.M., DinersteinE., Wikramanayake E.D., Burgess N.D., Powell G.V.N.,UnderwoodE.C., D'amico J.A., Itoua I., Strand H.E., Morrison J.C., Loucks C.J., Allnutt T.F., Ricketts T.H., Kura Y., Lamoreux J.F., Wettengel W.W., Hedao P. \& Kassem K.R. 2001. Terrestrial Ecoregions of the World: A New Map of Life on Earth. BioScience 51: 933-938. http://dx.doi.org/ 10.1641/0006-3568(2001)051[0933:TEO TWA]2.0.CO;2 
Orrico V.G.D. \& Kury A.B. 2009. A cladistic analysis of the Stygnicranainae Roewer, 1913 (Arachnida, Opiliones, Cranaidae) - where do longipalp cranaids belong? Zoological Journal of Linnean Society 157: 470-494. http://dx.doi.org/10.1111/j.1096-3642.2009.00543.x

Pinto-da-Rocha R. 1997. Systematic review of the Neotropical family Stygnidae (Opiliones, Laniatores, Gonyleptoidea). Archivos de Zoologia 33 (4): 163-342.

Pinto-da-Rocha R. \& Bonaldo A.B. 2011. Species relationships in the Neotropical genus Phareicranaus Roewer 1913 (Opiliones: Cranaidae): two new species and new data from penial morphology. Zootaxa 3135: 1-34.

Pinto-da-Rocha R. \& Kury A.B. 2003. Phylogenetic analysis of Santinezia with description of five new species (Opiliones, Laniatores, Cranaidae). Journal of Arachnology 31 (2): 173-208.

Piza Jr S.T. de 1942. A respeito da sistemática de alguns opiliões. Revista Brasileira de Biologia 2 (4): 403-416.

Porto W. \& Colmenares P.A. 2014. A new species of Avima, the first record of Agoristenidae (Opiliones: Laniatores) from the state of Roraima, Brazil. Zoologia 31 (6): 634-638.

QGIS Development Team 2014. QGIS Geographic Information System. Open Source Geospatial Foundation Project. Available from http://qgis.osgeo.org [accessed 27 Aug. 2015]

Ringuelet R.A. 1957. Anotaciones críticas sobre Opiliones de la subfamilia Pachylinae. Revista de la Sociedad Entomológica Argentina 19 (1-2): 17-20.

Roewer C.F. 1912. Die Familie der Cosmetiden Opiliones-Laniatores. Archiv für Naturgeschichte, Abteilung A 78 (10): 1-122. Available from http://biodiversitylibrary.org/page/13317265 [accessed 30 Aug. 2016]

Roewer C.F. 1913. Die Familie der Gonyleptiden der Opiliones-Laniatores. Archiv für Naturgeschichte, Abteilung A 79 (4): 1-256. Available from http://biodiversitylibrary.org/page/13325387 [accessed 30 Aug. 2016]

Roewer C.F. 1943. Über Gonyleptiden. Weitere Webernechte (Arachn., Opil.) XI. Senckenbergiana 26 (1-3): 12-68.

Šilhavý V. 1979. Opilionids of the suborder Gonyleptomorphi from the American caves, collected by Dr. Pierre Strinati. Revue suisse de Zoologie 86 (2): 321-334. http://dx.doi.org/10.5962/bhl.part.82296

Simon E. 1879. Essai d'une classification des Opiliones Mecostethi. Remarques synonymiques et descriptions d'espèces nouvelles. Première partie. Annales de la Société Entomologique de Belgique 22: $183-241$.

Towsend V.R. \& Milne M.A. 2011. Two new species of Manaosbiidae (Opiliones: Laniatores) from Panama, with comments on interspecific variation in penis morphology. The Journal of Arachnology 39: 92-101.

Townsend V.R., Bertram M.S. \& Milne M.A. 2015. Variation in ovipositor morphology among laniatorean harvestmen (Arachnida: Opiliones). Zoomorphology 134: 487-497. http://dx.doi.org/10.1007/s00435015-0269-4

Townsend V.R., Víquez C., Vanzandt P.A. \& Proud D.N. 2010. Key to the species of Cosmetidae (Arachnida, Opiliones) of Central America, with notes on penis morphology and sexual dimorphisms. Zootaxa 2414: 1-26.

Villarreal-Manzanilla O. \& Pinto-da-Rocha R. 2006. Five new species of Protimesius (Opiliones: Stygnidae) from Brazil. Zootaxa 1325: 219-233. 
Villarreal M.O. \& Rodríguez C.J. 2011. Revalidation of Santinezia albilineata Roewer, 1932 (Arachnida: Opiliones: Cranaidae). Journal of Threatened Taxa 3 (11): 2202-2206. http://dx.doi.org/10.11609/JoTT. $\underline{\mathrm{o} 2514.2202-6}$

Villarreal M.O., Kury A.B. \& Pinto-da-Rocha R. 2015. The poorly known genus Ventrifurca Roewer, 1913 revisited (Opiliones: Cranaidae). Zoological Studies 54 (45): 1-18. http://dx.doi.org/10.1186/ $\underline{\mathrm{s} 40555-015-0117-8}$

Villarreal M.O., Medrano M. \& Kury A.B. in press. Expanding the newcomers - a phylogenetic analysis of Nomoclastidae (Opiliones: Laniatores: Gonyleptoidea). Zoological Journal of the Linnean Society.

Walker E.A. \& Townsend V.R. 2014. Ovipositor morphology of cosmetid harvestmen (Arachnida, Opiliones, Laniatores): a new source of informative characters. Journal of Morphology 275 (12): 13761385. http://dx.doi.org/10.1002/jmor.20310

Manuscript received: 12 November 2015

Manuscript accepted: 3 May 2016

Published on: 10 November 2016

Topic editor: Rudy Jocqué

Desk editor: Kristiaan Hoedemakers

Printed versions of all papers are also deposited in the libraries of the institutes that are members of the EJT consortium: Muséum national d'Histoire naturelle, Paris, France; Botanic Garden Meise, Belgium; Royal Museum for Central Africa, Tervuren, Belgium; Natural History Museum, London, United Kingdom; Royal Belgian Institute of Natural Sciences, Brussels, Belgium; Natural History Museum of Denmark, Copenhagen, Denmark; Naturalis Biodiversity Center, Leiden, the Netherlands. 